\title{
A Systematic Literature Review about the Speed of Internationalization
}

\author{
Michael Neubert ${ }^{1}$ \\ ${ }^{1}$ UIBS - United International Business Schools, Switzerland \\ Correspondence: Michael Neubert, UIBS - United International Business Schools, Switzerland. E-mail: \\ michael.neubert@faculty.uibs.org
}

Received: November 9, 2021

Accepted: December 30, 2021

Online Published: January 15, 2022

doi:10.5539/ijbm.v17n2p80

URL: https://doi.org/10.5539/ijbm.v17n2p80

\begin{abstract}
The speed of internationalization or rapid internationalization is one of the most fascinating and researched topics in international business due to its practical importance for the international competitiveness of international firms. This paper aims to identify the determiners of internationalization speed using a systematic literature review of more than 50 current, peer-reviewed articles as research method. Based on an analysis of the topical evolution of the main internationalization theories, the main determiners of internationalization speed are categorized in environmental framing conditions, business resources, and business activities. To advance research about the determiners of internationalization speed, this paper suggests a conceptual framework of three research propositions about the impact of internationalization speed and its variations over time and in different industries and markets using sophisticated research methods to establish causal relationships.
\end{abstract}

Keywords: Internationalization, internationalization speed, speed of internationalization, fast internationalization, rapid internationalization; systematic literature review

\author{
Abbreviations \\ CEO (Chief Executive Officer) \\ SME (Small \& Medium-sized Enterprises) \\ TMT (Top Management Team)
}

\section{Introduction}

\subsection{Motivation and Research Issue}

Globalization, i.e. the process of international exchange resulting from human interaction and the interchange of material and immaterial goods (Albrow et al., 1994), is advancing at rapid pace. Macroeconomic research evaluates foreign investments mainly, which however are not assigned to individual economic entities (Belitz, 2015). Due to a lack of empirical data, internationalization remains a mythical concept (Altissimo, 2020). The growing together of nations has got important impacts on businesses, e.g. concerning supply chain interactions and sales market expansion (Lee et al., 2012; Tsao \& Chen, 2012).

Although a vast range of theories (Johanson \& Vahlne, 2009 \& 2020, Welch \& Luostarinen, 1988; Rasmussen \& Madsen, 2002) have been developed over decades now, uncertainty on potential determiners of business internationalization speed has rather been increasing than diminishing in recent years, due to controversial discussion on impacts, moderators and mediators in empirically founded contributions since 2015 (Vătămănescu, et al., 2017; Chang \& Ogasavara, 2019; Yoon, 2020; Freixanet \& Renart, 2020).

A range of systematic literature reviews specify recent research fields initiated since 2015 e.g. on the phenomenon of very rapid or early internationalization (Cesinger et al, 2012; Matiusinaite \& Sekliuckiene, 2015), the impact of internationalization on innovation $(\mathrm{Li}, 2020)$, and cognitive foundations of internationalization (Niittymies \& Pajunen, 2019). So far, however, no comprehensive overview on determiners of internationalization speed is available.

\subsection{Objective and Contribution}

This study closes this research gap and systematically evaluates peer-reviewed theoretical and empirical research 
in determiners of internationalization speed published since 2015 and including seminal theoretical papers in order to classify new theoretical and empirical insights on determiners of internationalization speed in the context of established internationalization theories. The research overview reveals important gaps in internationalization speed research, concretizes these empirical research gaps and calls for follow-up empirical studies addressing these.

The review reconnects established internationalization theories to topical empirical research in order to link the results to proven categories. Empirical research gaps are identified based on the framework and theoretical categories lacking empirical confirmation can systematically be revised and possibly be amended. This facilitates the work of follow-up empirical researchers.

\subsection{Review Method}

To tackle this fuzzy task systematically, some methodological considerations are indispensable:

To evaluate the ample body of theoretical and empirical research, two proven review methods are combined, Kraus' (2020) process model and Webster \& Watson's (2002) tabular method of literature evaluation using content and concept matrices. Eligible sources are extracted from three academic databases (scholar google, Web of Knowledge, Science Direct) referring to contributions in VHB ranked journals only. The retrieved studies are first organized in tables: The content matrix classifies by author and extracts determiners and results, while the follow-up concept matrix arranges results by determiners and forms categories of determiners. The textual presentation refers to the retrieved main categories to present the results by category and item.

Using this methodology, the theoretical part of the review (chapter 2) provides a synopsis of internationalization theories with special regard to explanations of internationalization speed in chapter 2. Important models of internationalization and seminal papers are gathered form earlier systematic reviews on internationalization (Paul \& Rosado-Serrano, 2019; Guserl, 2013; Swoboda, 2002; Kurtschker \& Schmid, 2006). Topical developments of the retrieved theories are collected by entering the model name AND "theory" plus the restriction "after 2015" in academic data bases and selecting theoretical contributions only. The theories and recent extensions are summarized in an author-based overview-table to extract determiners of internationalization speed from these theoretical models and classify them in order to organize the second part of the review.

The second review section (chapter 3) focusses on recent (from 2015) empirical research in determiners of internationalization speed. It again refers to contributions in peer-reviewed journals (VHB-ranking) from 2015 only which are extracted using the basic keyword combination ["internationalization speed" AND empirical AND determiner]. Empirically proven determiners of internationalization speed are collected from the retrieved studies by at first sorting results by author/ year, sample/ method, determiners/ moderator/ mediators, target parameters and observed effects in a content matrix (compare table 3). By reorganizing the overview by determiners and major categories, in a concept matrix referring back to the categories derived from the review of theoretical studies (compare table 4) the structure of the textual presentation is derived (Chapter 3).

The textual analysis of the retrieved empirical studies, summarizes and classifies the empirical impacts on internationalization speed. Based on the classification of empirical studies with regard to available theoretical frameworks, Chapter 4 identifies empirical research gaps and theoretical strands lacking empirical foundations and invites further empirical research to unite theory and empirics of research on determiners in internationalization speed.

\section{Theories of Internationalization and Their Topical Evolution}

A series of internationalization models have been suggested in an academic context (Paul \& Rosado-Serrano, 2019; Guserl, 2013; Swoboda, 2002; Kurtschker \& Schmid, 2006). The following overview extracts six representative models involved with internationalization speed and potential determiners of internationalization. A summary of the seminal \& most recent theoretical papers, identified internationalization patterns, their contribution to explain internationalization speed and critique are summarized in Table 1. 
Table 1. Overview on internationalization models and their assumptions on determiners of internationalization speed

\begin{tabular}{|c|c|c|c|c|}
\hline Model & $\begin{array}{l}\text { Content matrix - theoretica } \\
\text { Seminal \& most recent } \\
\text { studies }\end{array}$ & $\begin{array}{l}\text { studies on internationalizat } \\
\text { Internationalization } \\
\text { pattern }\end{array}$ & $\begin{array}{l}\text { models } \\
\text { Determiners of } \\
\text { internationalization } \\
\text { speed }\end{array}$ & Critique \\
\hline $\begin{array}{l}\text { Product-Lifecycle } \\
\text { Model }\end{array}$ & $\begin{array}{ll} & \text { Vernon (1966) } \\
\text { - } & \text { Kwon \& Hu, } 1995 \\
\text { - } & \text { Sikorski } \\
\text { Menkhof, 2000 } \\
\text { - } & \text { Hermansdottir, } 2008\end{array}$ & $\begin{array}{l}\text { - } \quad \text { Systematic } \\
\text { deterministic process } \\
-\quad \text { From high to low } \\
\text { wage countries }\end{array}$ & $\begin{array}{l}\text { Wage difference } \\
\text { of countries }\end{array}$ & $\begin{array}{l}\text { - Country \& product } \\
\text { rather than business } \\
\text { focus } \\
\text { - Obsolete due to } \\
\text { convergence of } \\
\text { economic development } \\
\text { - No timeline/ } \\
\text { statement on speed }\end{array}$ \\
\hline Uppsala Model & $\begin{array}{ll}\bullet & \text { Johanson \& Vahlne, } \\
\text { 1977, 2006, 2009, } 2015 \\
\bullet & \text { Welch et al., } 2016 \\
\bullet & \text { Humerinta et al., } \\
2015 & \\
\bullet & \text { Buckley \& } \text { Ghauri, } \\
2015 & \\
\bullet & \text { Verbeke, 2020 }\end{array}$ & $\begin{array}{l}\text { - Time \& location } \\
\text { related pattern } \\
\text { - Gradual exploration of } \\
\text { foreign markets } \\
\text { - Start by nearby and } \\
\text { culturally close countries } \\
\text { - from certain to } \\
\text { uncertain environments }\end{array}$ & $\begin{array}{l}\text { - Local \& cultural } \\
\text { distance } \\
\text { - Economic \& } \\
\text { political uncertainty } \\
\text { - Commitment of } \\
\text { company } \\
\text { - Relational } \\
\text { capabilities in supply } \\
\text { chain } \\
\text { Entrepreneurial } \\
\text { attitude } \\
\text { - Transaction costs } \\
\text { of going abroad }\end{array}$ & $\begin{array}{l}\text { - Basic version of } \\
\text { remoteness and cultural } \\
\text { distance }=\text { obsolete due } \\
\text { to globalization } \\
\text { - Pattern orientation } \\
\text { - Does not consider } \\
\text { Born-Globals }\end{array}$ \\
\hline Helsinki model & 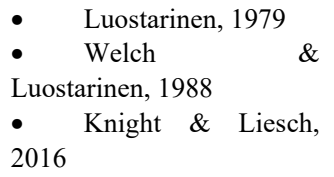 & $\begin{array}{lr}\text { - Lateral } & \text { rigidity } \\
\text { determines openness, pattern } \\
\text { and } \quad \text { speed } & \text { of } \\
\text { internationalization } & \end{array}$ & $\begin{array}{l}\text { - Size of local } \\
\text { economy } \\
\text { - Mental openness } \\
\text { - Cultural \& } \\
\text { economic distance }\end{array}$ & $\begin{array}{l}\text { - Mainly for SME } \\
\text { in small countries }\end{array}$ \\
\hline $\begin{array}{l}\text { Born } \\
\text { model }\end{array}$ & $\begin{array}{llr}\text { - } & \text { Rennie, } 1993 \\
\text { - } & \text { Knight \& } & \text { Cavusgil, } \\
\text { 1996 } & & \\
\text { - } & \text { Knight, } 1997 & \\
\text { - } & \text { Rasmussen et } & \text { al., } \\
2001 & & \\
\text { - } & \text { Andersson } & \text { \& } \\
\text { Wictor, 2003 } & \\
\text { - } & \text { Tanev, 2012 } \\
\text { - } & \text { de Oliverira } & \text { Cabral } \\
\text { \& Schaefer, 2016 } & \\
\text { - } & \text { Madson \& } & \text { Servai, } \\
\text { 2016 } & \\
\text { - } & \text { Freeman et al., 2010 } \\
\text { - } & \text { Knights \& Cavusgil, } \\
\text { 2015 } & \end{array}$ & $\begin{array}{l}\text { - Internationalizing } \\
\text { without prior competences } \\
\text { from initiation } \\
\text { - } 25 \% \text { of international } \\
\text { activities or sales within } \\
\text { three years from foundation }\end{array}$ & $\begin{array}{l}\text { - Low financial, } \\
\text { human \& tangible } \\
\text { resources } \\
\text { - Technological } \\
\text { competences } \\
\text { - High innovative } \\
\text { capacity and tacit } \\
\text { knowledge resources } \\
\text { - Networking } \\
\text { competences } \\
\text { activities } \\
\text { - International } \\
\text { culture } \\
\text { - Managerial } \\
\text { international } \\
\text { entrepreneurial } \\
\text { orientation }\end{array}$ & $\begin{array}{l}\text { - Practice-born } \\
\text { - No } \\
\text { internationalization } \\
\text { "timeline" - } \\
\text { - Are proprieties } \\
\text { relevant to "speed" at } \\
\text { all? }\end{array}$ \\
\hline GAINS model & $\begin{array}{l}\text { - } \quad \text { Mazarchina, } 1982 \\
\text { - } \quad \text { Mazarchina } \& \\
\text { Engelhard, } 1992\end{array}$ & 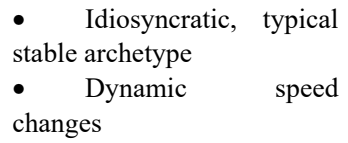 & $\begin{array}{ll}- & \text { environment } \\
- & \text { business structure } \\
- & \text { business strategy }\end{array}$ & $\begin{array}{l}\text { - determiners do not } \\
\text { indicate certain } \\
\text { internationalization } \\
\text { speed but dynamics }\end{array}$ \\
\hline Network view & $\begin{array}{lll}- & \text { Blankenburg } & \text { \& } \\
\text { Johanson, 1992 } & \\
\text { - } & \text { Forsgren et al., 2015 } \\
\text { - } & \text { Forsgren, 2016 } \\
\text { - } & \text { Forsgren } \\
\text { Johanson, 2014 } \\
\text { - } \quad \text { Ratajczak-Mrozek, } \\
\text { 2017 }\end{array}$ & $\begin{array}{l}\text { - Networks as primary } \\
\text { cause and driver of } \\
\text { internationalization } \\
\text { - Explains born global } \\
\text { or proces }\end{array}$ & $\begin{array}{lr}-\quad \text { Network } & \text { alliance } \\
\text { orientation } & \\
\text { (organizational } & \& \\
\text { managerial9 } & \\
-\quad \text { Network } & \text { alliance } \\
\text { structure } & \end{array}$ & $\begin{array}{l}\text { - Networks as a } \\
\text { priori phenomenon or } \\
\text { secondary effect }\end{array}$ \\
\hline
\end{tabular}

Classical process models, understanding internationalization as a gradual process (e.g. Uppsala Model: Johanson \& Vahlne, 2006) have been superseded by Born-global models (Chetty \& Campbell-Hunt, 2004), understanding internationalization as an innate business approach, gestalt models (e.g. GAINS model (Forsgren \& Pahlberg, 
1992; Wührer, 2015), which find internationalization a phenomenon defined by a set of external and internal parameters and the network view which sees business networks as origin and basic phenomenon of internationalization (Forsgren \& Johanson, 1992; Chetty, 1994).

The Product-Life-cycle model, internationalization process model and the Helsinki model count have been referred to as gradual or process models in secondary literature (Paul \& Rosado-Serrano, 2019, Guserl, 2013):

\subsection{Product-Life-Cycle Model (Vernon, 1966/2004)}

Vernon's (1966/2004) product life cycle model originates in a production-marketing context and sees internationalization as a systematic, incremental and predictable sequence of strategic decisions (Kwon \& Hu, 1995; Sikorski \& Menkhoff, 2000). In its initial phase a product is entirely produced and sold in a (high wage) country of origin until a point of saturation is reached. The company has to open up new international sourcing and distribution markets to grow further. Gradually, the supply the chain is displaced to low wage sourcing countries in order to diminish production costs (Hermannsdottir, 2008). As a result, the product is marketable in foreign countries too finally, which leads to an internationalization of the whole product life cycle and the global profusion of the product (Hill, 2007). Vernon's model has been criticized for its product and country rather than business orientation (Melin, 1992) and seems obsolete in a globalized world in which the classification of countries into advanced high-wage and developing low-wage nations blurs (Vernon, 1979). The model lacks a timeline according to which the internationalization process occurs and is little flexible due to its stage orientation (Kutschker \& Schmid, 2011).

Due to its focus on stages and lacking concreteness on internationalization speed the model hardly allows any conclusions on determiners of internationalization speed except the probably the developmental and wage-related distance between origin and target country.

\subsection{Uppsala Internationalization Process Model (Johanson \& Vahlne, 1977/2009/2015)}

Like the Product Life Cycle Model, the Uppsala Internationalization process model sees internationalization as a gradual process, but is more precise distinguishing a time and location related pattern of internationalization (Elgar, 2003). The time pattern assumes that businesses first gather experience in their local market, gradually establish representations abroad and establish remote production units to finally open up international sales markets. The local pattern suggests that businesses first expand to culturally similar and nearby countries before exploring remote and culturally distant locations (Johanson \& Wiedersheim-Paul, 1975; Johanson \& Vahlne, 1977). Local and cultural distance accordingly moderate internationalization speed (Welch et al., 2016). Arguing that the internationalization process as suggested by the Uppsala model is continuous and defined by the requirements of individual businesses, Welch et al. (2016) encounter the frequent critique of the Uppsala model as a "stage model" (McDougall et al., 1994). Businesses fully ignore markets they do not understand or know (Hurmerinta et al., 2015).

To encounter the critique that cultural and local distance diminish in relevance in the age of digital markets and modern transportation (Alvesson \& Sandberg, 2011), Johanson \& Vahlne (2009) update their model and distinguish supply-chain ingroups and outgroups and (politically and economically) uncertain as compared to certain marketst explain businesses internationalization behavior (Verbeke, 2020; Buckley \& Ghauri, 2015).

Applying social network theory Yamin \& Kurt (2014) develop the Uppsala Model further and suggest that the "liability of foreigness" corresponds to a "liability of outsidership" in business networks and impairs information flows from insider in the network to outsiders. Information deficits are transaction costs which are avoided by investing in network access. The positional attributes of the network insider codetermine the intended entry speed of the outsider (Blankenburg et al., 2015).

The Uppsala model could accordingly be understood as a model of entrepreneurship, suggesting that an entrepreneurial proactive and risk-taking attitude promotes internationalization speed (Forsgren, 2016). Vahlne \& Bhatti (2019) finally interpret their model as an evolutionary model, in which evolution is driven by the relational capabilities and relationship commitment processes of the firm, where commitment contributes to develop internationalization capabilities (Vahlne \& Johanson, 2017).

In sum, interpretations of the Uppsala Model identify a series of determiners of internationalization speed, which in the model's basic version are local and cultural remoteness and in its novel form are economic and political uncertainty, insider network seclusion and finally relational competence and the entrepreneurial spirit of the expanding company. 


\subsection{Helsinki Model (Luostarinen, 1979 / 1994)}

The Helsinki model has originated from research in the internationalization processes and strategies of small and medium sized companies in Northern European countries (Luostarinen, 1979; Luostarinen, 1994). It shows some parallels to the Uppsala model but equally to Penrose's (1959) theory of business growth (cit. from Buckley \& Casson, 2007) and Ansoff's (1965) knowledge-based decision theory (O'Farrell \& Hitchens, 1988).

The Helsinki model is grounded on the concept of "lateral rigidity", which indicates the extent to which a business is inclined to change its actual patterns of behavior and to which it is active or passive in its decisions and activities and reduces its potential action range depending on earlier decisions (Welch \& Luostarinen, 1988). High lateral rigidity prevents businesses from changing earlier decisions and predetermines their internationalization paths (Luostarinen, 1979). Lateral rigidity results in incremental, sequential and cumulative internationalization processes: Businesses first are reluctant to expand and then stick to their internationalization plans (Swoboda, 2002).

Beyond companies' decision orientation Luostarinen (1979) sees the size and openness of the companies' economy of origin as a determiner of internationalization speed: businesses from small economies are forced to internationalize early to open up new markets and open economies ease this step. External preconditions codetermine why some businesses seem to be born global or internationalize at rapid pace (Luostarinen \& Gabrielsson, 2006). Corresponding to the Uppsala model, the Helsinki model sees the difference of conditions in the home as compared to the target country as decisive: Low economic cultural and physical distance ease and accordingly speed up internationalization (Luostarinen, 1979). The Helsinki model allows for jumps and turns in businesses' internationalization process due to low lateral rigidity and thus is more flexible to business specificity (Welch \& Luostarinen, 1988).

Due to its broader theory base and larger range of determiners critique of the Helsinki model is less pronounced than of the Uppsala model (Welch \& Luostarinen, 1988). Its focus on SME in small countries however have brought the model less international attention and development (Knight \& Liesch, 2016).

\subsection{Born Global Model - Internationalization as an Innate Strategy}

While the above process models see internationalization as a gradual and emerging process, the born-global model of internationalization suggests that "being an international company" is inherent in businesses' strategy from scratch:

The Born Global theory of internationalization emerged in the 1990ies from a series of studies in the context of the consulting agency McKinsey (Rennie, 1993) which did not find the classical patterns of gradual internationalization processes reproducible for a certain new type of companies (Knight, 1997). Typical Born Globals are from initiation designed to operate in an international environment and serve a global market (Knight \& Cavusgil, 1996), they internationalize at rapid pace shortly after their foundation (Harveston et al., 2000) and do this in several countries at once even without prior knowledge or capabilities concerning any market. Rasmussen et al. (2001), Andersson \& Wictor (2003) and Cavusgil et al. (2014) agree that Born Globals reach a share of $25 \%$ of foreign sales or international activities within three years after starting operations.

Born Globals have been found to dispose of particular resources that differentiate them gradually internationalizing companies. They serve their own niche markets (Knight \& Cavusgil, 1996) and usually provide products of superior quality. They usually lack financial, human and tangible resources (Knight \& Cavusgil, 2004), but leverage certain idiosyncratic technological competences frequently in the field of information and communication technologies (Tanev, 2012). Freeman et al. (2010) put the enormous internationalization potential and dynamics of Born Globals down to high resources of tacit knowledge, innovation capacity and entrepreneurial skill. They frequently rely on international market participants and partners and dispose of strong networking competencies (Tanev, 2012; Andersson \& Wictor, 2003; Gabrielsson \& Kirpalani, 2004). Managers of born globals usually dispose of a strong international entrepreneurial orientation (de Oliverira Cabral \& Schaefer, 2016), visionary beliefs and an organizational culture that eases operation in an international environment (Andersson \& Evangelista, 2006; Cavusgil \& Knight, 2015).

The contribution of "born global models" to internationalization speed is at first sight questionable since the proprieties assigned to born global on the one hand promise innate internationalization, which would marginalize the question of speed. Madsen \& Servais' (2016) critique of the Born Global concept, however, justifies citing the model in the context of internationalization speed: the authors complain lacking differentiation of the born global from evolutionary internationalization models, since Born Globals just run through the gradual process at a very rapid pace (Madsen \& Servais, 2016). Born Global proprieties are thus just powerful drivers of 
internationalization speed.

\subsection{Gestalt-Approach (GAINS model; Macharzine \& Engelhard, 1991)}

The GAINS model (Gestalt approach of International Business Strategies) was initiated by a publication of Macharzina \& Engelhard (1991) in reaction to growing sophistication and low precision of term usage in established process models of internationalization. The authors intend to focus rather on determiners than on dynamic process patterns of internationalization (Macharzina, 1982). Macharzina \& Engelhard (1992) differentiate five archetypes of internationalization which each dispose of an inherent pattern of logics and dynamics, which is comprehensive and conclusive by itself and stable in time (Wührer, 2015). Changes in internationalization character between the archetypes are exceptional (Macharzina \& Wolf, 2005). To define an archetype, Macharzina \& Engelhard (1992) identify a "gestalt rationale", i.e. frequent, typical and significant patterns of internationalization, which are defined by environmental, structural and strategical variables and thus characterize an archetype (Macharzina \& Engelhard, 1991). Archetypes run through different phases in their internationalization process, where stable and dynamic phases alternate, while the basic environment, structure and strategy remain the same (Macharzina \& Engelhard, 1991; Macharzina, 1982).

The gestalt-approach to internationalization indicates a clear main pattern of determiners of internationalization speed, which comprises environmental factors, structural factors and strategic factors. This category system is open to comprise diverse determiners of internationalization speed (Swoboda, 2002). However, according to the GAINS model these determiners do not indicate a steady or predictable speed of internationalization but only a typical dynamic behavior. Jumps from one "gestalt" of internationalization to the next are typical for any archetype (Kutschker \& Schmid, 2006). This would mean that predicting internationalization speed based on the parameter set would not be possible.

\subsection{Network View (Forsgren \& Johanson, 1992)}

The network view assumes that businesses' internationalization behavior is determined by their business network relationships. Business networks are interlinked relationships between two or more participants controlling business activities and resources (Forsgren \& Johanson, 1992; Chetty, 1994). Every company is part of a network of suppliers and market partners and its position in that network codetermines the long-term strategic orientation of the firm. Internationalization takes place or is speeded up, when the business participates in an international network or the management shows high international orientation or engagement (Chetty et al., 2000; Blankenburg \& Johanson, 1992), in brief when the organizational orientation or managerial relational activity is international (Ratajczak-Mrozek, 2017). The network approach represents the orientation of many Swedish SME which originating in a small country are a priori established in an international network environment (Forsgren et al., 2015).

Johanson \& Vahlne (2009) and further authors (e.g. Yamin \& Kurt, 2014) integrate the network perspective into the Uppsala process model, arguing, that internationalization is an entrepreneurial process, leading businesses to get involved with international business networks gradually. Forsgen (2016), initiator of the network approach, criticizes this concept arguing that network activity is a primary activity of internationalizing businesses, while the amended Uppsala model sees businesses as network outsiders first and points out that they gradually phase into international networks (Johanson \& Vahlne, 2009; 2015). Network positioning, according to Forsgren et al. (2015) is - in accordance with the gestalt approach - a strategic orientation of the business and - in correspondence with the born global model- can define the initial international positioning of a start-up (Wührer, 2015).

The network approach to internationalization accordingly takes an intermediate position between the born Global perspective and (Tanev, 2012; Andersson \& Wictor, 2003; Gabrielsson \& Kirpalani, 2004) the Gestalt approach (Macharzina \& Engelhard, 1991). The network approach positions the business network as a primary phenomenon in the tradition of gestalt theory, assuming that businesses are from the beginning part of an entrepreneurial network of a certain shape (Forsgren \& Johanson, 2014). Network affiliation depends on the strategic orientation and competences of the business of course. This has brought the network approach the critique of positioning networks as an input dimension, although they are in fact the result of earlier strategic decisions and resource base. The diverging argumentations of Forsgren et al. and Johanson Vahlne $(2009,2015)$ certainly prove that, other than the Born Global model, the network approach is flexible to model businesses' gradual orientation towards or equally their jump start in an international network.

\subsection{Towards a Classification System of Determiners of Internationalization Speed}

Table 1 summarizes the results of the theoretical section of the review (chapter 2), which has juxtaposed six 
internationalization theories with regard to their perspective on internationalization speed. While Product-Life Cycle, Uppsala and Helsinki model of internationalization count among the so-called process models and understand internationalization as a gradual planned and directional process, more recent models, i.e. the born global model, the GAINS and model and the network view focus on the phenomenon of internationalization itself, showing that business strategy, resources and external business networks determine the shape (gestalt) of internationalization and internationalization speed. These are referred to as phenomenological approaches in the following. Increasingly interconnections between both perspectives have been drafted particularly in the field of network research (Johanson \& Vahlne, 2009, 2015).

The perspectives on determiners of internationalization have been subject to change with the evolution of internationalization theories from a process to a strategic perspective: process-oriented models of internationalization focus on environmental determiners of internationalization. According to Vernon (1966) the wage difference between developed and emerging countries is the major internationalization impetus. The Uppsala Model sees local and cultural distance and in later versions economic and political uncertainty (Welch et al., 2016) as important environmental factors, but equally considers aspects at the level of business capabilities and commitment: e.g. relational competence in the supply chain, and entrepreneurial attitude as determiners of internationalization speed. Similarly, the Helsinki model considers environmental (size of local economy, cultural \& economic distance) as well as firm specific factors (mental openness) with a special focus on Nordic SME.

The younger phenomenological models (Born-Global, GAINS and network view) analyze firm specific determiners of internationalization in more detail, while environmental determiners lose in importance in these models. The differentiation of resource related and activity related determiners is found in all three models: Resource related aspects comprise financial, human and tangible means (Born Global model; Knight \& Cavusgil, 1996, 2015), technical competences, innovative competences Knight 1997; Freeman et al., 2010), business structures (GAINS model: Mazarchina \& Engelhard, 1992) and network alliance structures (network view, Forsgren et al., 2016).

Activity related determiners comprise international cultural and managerial orientation in the born global model (Knight \& Cavusgil, 1996, 2015), business strategy in the GAINS model (Mazarchina \& Engelhard, 1992) and network alliance orientation at the level of organization and management according to the network view (Forsgren et al., 20015/ Forsgren, 2016). Table 2 designed in the form of a concept matrix (Webster \& Watson, 2002) summarizes the three fields of determiners of internationalization speed as available from previous research. It provides a category system of framing factors, resource-related and activity-related determiners of internationalization speed derived from the evaluation of internationalization theories and is applied to classify empirical results in chapter 3 .

Table 2. Category system of determiners of internationalization speed

\begin{tabular}{|c|c|c|c|c|c|}
\hline \multirow[t]{2}{*}{ Concept matrix } & \multicolumn{5}{|c|}{ Determiners of internationalization speed according to theoretical literature } \\
\hline & Main & Authors & $\begin{array}{l}\text { Environmental framing } \\
\text { conditions }\end{array}$ & $\begin{array}{l}\text { Resource-related } \\
\text { determiners }\end{array}$ & $\begin{array}{l}\text { Activity-related } \\
\text { determiners }\end{array}$ \\
\hline $\begin{array}{l}\text { Product-Lifecycle } \\
\text { model }\end{array}$ & $\bullet$ & Vernon (1966) & - $\quad$ Wage differences & & \\
\hline Uppsala Model & $\begin{array}{l}\bullet \\
1977,2\end{array}$ & $\begin{array}{l}\text { Johanson \& Vahlne, } \\
2006,2009,2015\end{array}$ & $\begin{array}{l}\text { - } \quad \text { Local distance } \\
\text { - } \quad \text { Cultural distance } \\
\text { - } \quad \text { Economic \& } \\
\text { political uncertainty }\end{array}$ & $\begin{array}{l}\text { - Relational } \\
\text { capabilities }\end{array}$ & $\begin{array}{l}\text { - Corporate } \\
\text { commitment } \\
\text { - Entrepreneurial } \\
\text { attitude }\end{array}$ \\
\hline Helsinki Model & $\begin{array}{l}\bullet \\
\bullet \\
\text { Luosta } \\
\bullet \\
2016\end{array}$ & $\begin{array}{l}\text { Luostarinen, } 1979 \\
\text { Welch \& } \\
\text { arinen, 1988 } \\
\text { Knight \& Liesch, }\end{array}$ & $\begin{array}{l}-\quad \text { Size of local } \\
\text { economy } \\
\text { - Cultural distance } \\
\text { - Economic } \\
\text { distance }\end{array}$ & - $\quad$ Mental openness & $\bullet$ \\
\hline Born-global Model & $\begin{array}{l}\bullet \\
1996 \\
\bullet \\
\bullet \\
2015\end{array}$ & $\begin{array}{l}\text { Knight \& Cavusgil, } \\
\text { Knight, } 1997 \\
\text { Knights \& Cavusgil, }\end{array}$ & & $\begin{array}{l}\text { - } \quad \text { Financial, human \& } \\
\text { tangible resources } \\
\text { - } \quad \text { Technological } \\
\text { competences } \\
\text { - } \quad \text { Networking } \\
\text { competence }\end{array}$ & $\begin{array}{l}\text { - International } \\
\text { culture } \\
\text { - Managerial } \\
\text { orientation } \\
-\quad \text { Networking } \\
\text { activity }\end{array}$ \\
\hline
\end{tabular}




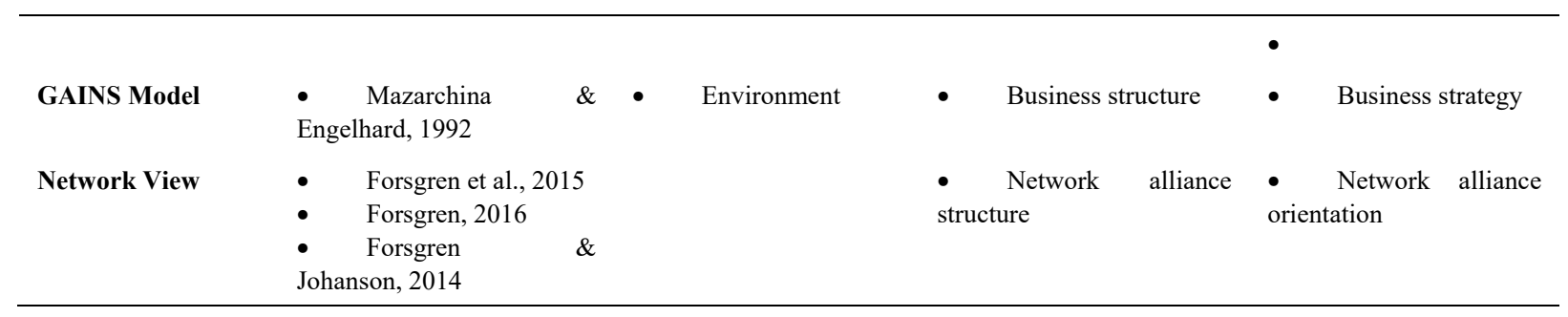

\section{Determiners of Internationalization Speed}

Section 5.3 classifies the empirical insights based on the content matrix in section 5.2 and the concept matrix ins section 5.3 to derive main- and sub-categories systematically. The following argumentation follows this items arrangement.

\subsection{Environmental Framing Conditions}

In the understanding of the Uppsala model (Johanson \& Vahlne, 1977, 2006, 2009, 2015) and Helsinki model (Luostarinen, 1979; Welch \& Luostarinen, 1988) of internationalization environmental factors explain internationalization speed to a large extent. Empirical studies confirm the relevance of diverse framing factors which control or moderate internationalization speed. These comprise a) sectoral conditions, b) conditions in the home market and c) in the target market.

\subsubsection{Sectoral Framing Conditions}

Four studies explain that internationalization speed depends or is controlled by the business sector of the companies in their samples. Amorós (2016) finds that businesses in the extractive sector internationalize more rapidly than others, since these depend on international distribution networks. According to Mihailova et al.'s (2015) study among Russian new ventures, technology intensive businesses excel in internationalization speed, when the size of domestic markets for these technologies is limited. Conclusively, Rialp-Criado \& Rialp (2020) find export intensity and business sector (B2B as compared to B2C) a reliable positive moderator of the impact of speed of use of social media on internationalization speed. The application of digital technologies in the sector speeds up internationalization activities according to Neubert's (2018a) qualitative study among lean global start-ups.

\subsubsection{Framing Conditions in the Home Market}

In several qualitative empirical studies among born-global high-tech companies from small economies (focus Switzerland), Neubert et al. (2016a, 2017, 2018a) identify important conditions to internationalization speed in the home country. When businesses depend on self-reliantly acquired financial resources, while government funds are unavailable, they are more open to internationalization (Neubert \& Van der Krogt, 2017) and internationalize more quickly in order to gather the necessary financial means abroad. The necessity to rely on venture capital or other external private equity drives businesses to grow in the interest of these important external shareholders (Neubert et al., 2016a).

Companies from small economies tend to follow a born-global strategy since home markets are too small to enable necessary growth and scale effects (Mihailova et al., 2015). Start-ups ensure their survival by taking recourse to international distribution channels from very early onwards (Neubert \& Van de Krogt, 2017). Torkkeli et al.'s (2019) survey among Finnish SME confirms the high relevance of institutional factors in the country of business origin. Companies internationalize when their local markets do not provide enough customers and if domestic legislation or cultural attitude do not significantly hamper international activities. Mihailova et al. (2020) find similar conditions for Russian new ventures: unfavorable regulative institutional conditions in the domestic economy push them to internationalize very soon. The availability of institutional norms for international growth in the country of origin encourage degree and scope of new venture internationalization further.

\subsubsection{Framing Conditions in the Target Countries}

The framing conditions in target markets of internationalization activities are highly significant. The retrieved studies address

a) physical and mental distance of target destinations (Cheng et al., 2020; Wild 2020, Neubert, 2018b; Ooi \& Richardson, 2020; Clermonts, 2019; Schu et al., 2016; Hutzschenreuter et al., 2016), 
b) characteristics of foreign distribution markets (Bemborn, 2018; Clermonts, 2019, Du et al., 2020; Mihailova et al., 2015; Himerson \& Johanson, 2015)

To a) Cultural distance of target destinations impedes the internationalization speed of Chinese companies of the Yangtze river delta (Cheng et al., 2020) but equally the internationalization of Western high-tech SME (Wild, 2020). Apart from geographic distance, the psychic distance of foreign destinations hampers internationalization activities, when businesses dispense with local connections and do not understand idiosyncratic business conditions (Wild, 2020). Interviews with Malayan management consultants confirm the challenge of psychic distance in developing international alliances and trustful partnerships abroad (Ooi \& Richardson, 2020). Multinational companies from emerging countries complain the barrier of institutional distance in their expansion activities to industrialized countries (Clermonts, 2019). Even online retailers' international engagements are limited by the degree of distance of new country markets. With growing distance of the target market and growing diversity of international engagements internationalization process length extends (Schu et al., 2016). Institutional, language, economic and geographical proximity and psychic distance, however, are insignificant in a Cox-Hazard regression model explaining the entry speed of Chinese internationalizing companies in emerging or industrialized target countries (Du et al., 2020). Possibly, the distance-effect is diluted in this model due to the broad range of applied distance-related parameters for a single regression.

To b) The conditions in the target market encourage or impair internationalization. Bemborn (2018) and Clermonts (2019) assess the "absorptive capacity" of foreign markets and find this characteristic decisive to internationalization speed of German businesses (Bemborn, 2018) and businesses from emerging countries (Clermonts, 2019) alike. Du et al. (2020) explain that the development status of the target country codetermines entering businesses' internationalization speed. Depending on the development status of the target country, different entry strategies prove: In developed countries acquisitions result in the highest entry speed, while in developing countries pure export strategies promise faster entry success. Broad foreign target markets readily absorb internationalizing Swedish SME (Hilmerson \& Johanson, 2015).

In sum section 3.1 results in a first research proposition:

P1: Framing conditions - specifically, business \& sectoral characteristics, institutional conditions in the home market and distance as well as market characteristics in the foreign target country control and moderate business internationalization speed.

\subsection{Business Resources as Determiners of Internationalization Speed}

All the above cited studies however emphasize the that environmental conditions are never the only driver or impediment of internationalization speed, but usually controls or moderators. Business resources are the fundamental active determiners of internationalization activities. These comprise a) managerial competences \& experience, b) knowledge resources and c) material resources.

\subsubsection{Framing Conditions at the Company Level}

Internationalization speed has conclusively been found to diminish with company age (Amann, 2016; Chun et al., 2020; Du et al., 2020; Mihailova et al., 2015). Amann (2016) concretizes that the speed of Swiss SME expansion abroad diminishes with the age at internationalization set-off and remains a delaying factor even in the mid- and long term i.e. for 21 years from initiation. Korean exchange traded firms as well as innovative Chinese businesses significantly diminish their internationalization speed with growing age (Chun et al., 2020; Du et al., 2020). Results concerning the impact of firm age on internationalization performance, however, diverge, while Lattemann et al. (2015) superior performance for younger Chinese MNC, Chun et al. (2020) and Du et al. (2020) find the moderate pace of older Chinese businesses more successful.

Firm size, on the other hand, usually stands in positive relationship with internationalization speed of innovative Chinese businesses (Chun et al., 2020) as well as UK SME (Idris \& Sadirakis, 2018). According to Jain et al.'s (2019) results for Indian IT companies and Idris \& Saridakis (2018), firm size is correlated to business network size, leveraging and linkage capabilities, which, as section 3.3 will show, additionally speed up internationalization. Polish businesses internationalization advances positively depend on their number of employees. Two studies find firm size ambiguous or even a negative control of internationalization: Russian companies' degree of internationalization diminishes with firm size, possibly due to the sample's industry focus in the extractive sector (Mihailova et al., 2015). Energy providers' size is no significant moderator of the impact of social media usage speed on internationalization speed (Rialp-Criado \& Rialp. 2020).

\subsubsection{Managerial Competences and Entrepreneurship}

Empirical studies identify multiple managerial, i.e. CEO and top management team (TMT), competences 
contributing to rapid internationalization. These comprise:

a) managerial education and training (Amorós, 2016; Chang \& Mao, 2015; Neubert \& Van der Krogt, 2017; Vlacic, 2018),

b) managerial experience (Chahabadi, 2015; Lin et al., 2016, Chang \& Mao, 2015; Chun et al, 2020; du et al., 2020, Mihailova et al., 2015, Genç, 2016; Mohr et al., 2018) and

c) entrepreneurial attitudes (Hsieh et al., 2019; Fahalat, 2018; Lin et al., 2016; Saghebi et al., 2019; Wach et al., 2018).

To a) Managerial cognitive reasoning is correlated to future entrepreneurs' intention to internationalize early (Vlacic, 2018). Highly educated Chilean entrepreneurs internationalize earlier. Swiss and Paraguayan high-tech startups internationalize early and fast, if led by internationally educated founders and if they dispose of qualified international staff resources (Neubert \& Van der Krogt, 2017). A sample of more than 9,000 international retail SME depend on managerial international experience and geographical fungibility to maintain their international engagement after rapid expansion (Mohr et al., 2018).

To b) Chinese born globals of Zhejiang depend on managerial entrepreneurial orientation and global expertise in their internationalization process (Lin et al., 2016). Managers in the German renewable energy industry however step down their international engagements with growing international experience (Chahabadi, 2015). Prior international experience of the management team has usually been found a success factor in internationalization processes: Shanghai-based tech-companies use this resource for international alliancing and market development (Chang \& Mao, 2015). Korean exchange traded companies with dense international affiliations rely on international CEOs and TMT experience (Chun et al., 2020).Both resources are equally valuable to Chinese start-ups in emerging markets (Du et al., 2020) and Russian companies' export activities (Mihailova et al. 2020). Managerial international expertise moderate the impact of alliance formation and marketing efforts on internationalization speed and performance (Genç, 2016; Mohr et al., 2018).

To c) Internationalization speed depends on managers' entrepreneurial instinct. While for a sample of $180 \mathrm{SME}$ in six economies firms' international experience impairs the speed of international deepening and geographic diversification, entrepreneurs' international business experience partly compensates this effect (Hsieh et al., 2019). Referring to Lumpkin \& Dess' (2015) entrepreneurial orientation construct, Fahalat (2018) finds positive effects on international performance and expansion for a representative sample of service businesses. Iranian SME's internationalization speed depends on managers' entrepreneurial orientation mainly (Saghebi et al., 2019). Polish businesses internationalization benefits of managerial entrepreneurial orientation and particularly on the readiness to accept risks (Wach et al., 2018). Du et al. (2020) emphasize the relevance of managerial innovativeness and Amor's (2016) the necessity of opportunity orientation in internationalization processes. Swiss high-tech start-ups depend on the entrepreneurial skills of the top management to excel in internationalization speed (Neubert, 2016b). Paraguayan software firms' internationalization speed is defined by the entrepreneurial traits of the management team (Neubert \& Van der Krogt, 2020).

\subsubsection{Corporate Knowledge and Innovation Resources}

Corporate knowledge resources are an important success factor of internationalization and increase internationalization speed. Empirical studies differentiate

a) target market knowledge (Chang \& Mao, 2015; Wach et al., 2018),

b) technology \& innovation knowledge (Chun et al., 2020; Du et al., 2020; Ivanauskiene et al., 2015),

c) institutional knowledge (Eriksson et al., 2015; Hutzschenreuter et al., 2016) and

d) social knowledge (Jain et al., 2019; Ooi \& Richardson, 2020; Du et al., 2020).

e) external knowledge \& advice (Abrahamson, 2018; Bolzani, 2017, Du et al., 2020; Hillmerson \& Johanson, 2015)

To a) Market knowledge enables Shanghai high-tech tart-ups to rapidly establish worldwide (Chang \& Mao, 2015). Polish businesses benefit of target market knowledge in the early internationalization phase and take recourse to networking, entrepreneurial and cultural knowledge in later stages of the internationalization process. All four knowledge aspects increase internationalization scope and scale (Wach et al., 2018).

To b) Chun et al. (2020) identify the availability of patents and technological knowledge as positive determiners of Korean exchange traded companies' international expansion speed and creativity as a positive moderator of this relationship. Du et al. (2020) classify the number of patents granted by international patent offices as 
international innovation ability and find a positive causal relationship with internationalization speed of Chinese high-tech businesses in developing countries, while the factor is insignificant for developed countries. Technology orientation moderates the effectiveness of e-marketing for Baltic SME and is key to rapid internationalization of these businesses (Ivanauskiene et al., 2015).

To c) Swedish service businesses' institutional and business knowledge of target markets diminishes the cost of internationalization and sets free resources for speeding up internationalization intensity and scope (Eriksson et al., 2015). Business units of established German multinationals increase in internationalization speed with growing parents' relatedness and reliance on international expertise. They benefit of direct and indirect learning processes from the mother corporation (Hutzschenreuter et al., 2016).

To d) Based on a longitudinal study, Jain et al. (2019) explain high internationalization speed of Indian software companies by learning, leveraging and linkage capabilities with international networks. Du et al. (2020) name similar capabilities "multidimensional proximity" and find this characteristic crucial to the internationalization speed of innovative Chinese businesses in emerging markets.

To e) A broad external knowledge base has only partly been found useful to speed up internationalization processes. Although Abrahamson (2018) finds no significant impact of external venture capital on internationalization speed of Swedish start-ups, he observes that born-globals are more frequently backed by venture capitalists and put this down to their coaching and consulting influence. Hilmerson \& Johanson (201) find a U-shaped effect of businesses' commitment to international knowledge resources on internationalization speed. A high number of external shareholders impairs internationalization speed of Italian university spin-offs (Bolzani, 2017), while a homogenous ownership structure has got an accelerating effect on the internationalization process of innovative Chinese companies (Du et al., 2020).

\subsubsection{Financial Resources}

Only two authors address the relevance of financial resources (Bolzani, 2017; Schu et al., 2016) to internationalization: Firm equity is a positive determiner internationalization speed of Italian university spinoffs (Bolzani, 2017). Venture capital availability is a reliable positive predictor of online shops' internationalization speed of and enables businesses to extend their scope and depth of internationalization quickly (Schu et al., 2016).

\subsubsection{Innovative Products}

Innovative products and technologies demand and promote internationalization activities: New technology usage supports the early internationalization of Chilean entrepreneurs (Amorós, 2016). Firm creativity is a positive moderator of internationalization activities of Korean exchange traded companies (Chun eta 1., 2020). Hsieh et al. (2019) emphasize the high relevance of a comprehensive innovation strategy for SME in the clothing, software and biotech industry in six economies. Innovation means looking out for opportunities and developing knowledge systematically. These dynamic capabilities enable businesses to launch internationalization strategies successfully (Vahlne \& Bhatti, 2019). Knowledge Utilization increases scope and speed of Polish companies' internationalization processes (Wach et al., 2018).

Internationalization degree and scope depend positively on the marketability of innovative products for Russian new ventures (Mihailova et al., 2015). Neubert (2016a) and Neubert \& Van der Krogt (2017) observe for Swiss high-tech start-ups and similar businesses from other small economies that businesses offering disruptive technologies and using cloud-based data management and acquisition technologies are first to internationalize since these products evoke market interest globally, while local markets are usually too small to cover initial high R\&D efforts. Technological uniqueness and a specific product portfolio ensure the survival and further growth of Swiss high-tech start-ups abroad (Neubert, 2016a). Online shop imitability has a U-shaped impact on the number of days to internationalization of an international sample of online-retailers, an intermediate imitability minimizes internationalization time accordingly (Schu et al., 2016).

Summarizing section 3.2 a second proposition is derived:

P2: Business resources, particularly managerial international experience and entrepreneurial capabilities, corporate knowledge financial resources and innovative products speed up internationalization processes.

\subsection{Business Activities as Determiners}

Beyond resources, businesses activities and engagement in the internationalization process are essential to speed up internationalization sustainably. An extensive set of relevant activities has been addressed, which comprises proactive digital marketing, corporate learning, strategic planning and - most important - networking. 


\subsubsection{Proactive Digital Marketing}

A proactive digital marketing strategy has been found preconditional to international expansion. For companies from emerging markets, marketing strategy mediates the impact of entrepreneurial orientation and networking capabilities on foreign market performance and equally improves foreign market performance directly (Falahat, 2018). Since disruptive technologies prosper in international markets, innovative companies in Switzerland depend on a successful international marketing set-up (Neubert, 2016a). To open up global market niches rapidly internationalizing businesses in the high-tech sector rely on lean but thoroughly tailored market development concepts (Neubert, 2017). Rialp-Criado \& Rialp (2020) explain that the speed of social media usage for marketing as well as website design are direct determiners of internationalization speed for energy providers. Ivanauskiene et al. (2015) confirm this for Baltic SME.

Businesses of the energy sector employ broad digital marketing strategies and social networks to acquire customers internationally and thus speed up their internationalization process (Bovina, 2020). Neubert (2018b) on the other hand explain that Swiss SME rely on lean and targeted digital strategies to offer their innovations abroad. The establishment of international sales partnerships relies on digital tools and accelerates international growth (Neubert, 2018b).

\subsubsection{Targeted Corporate Learning}

Commitment to organizational learning has proven a multiplier of internationalization speed. Experiential learning through social network partnerships and international alliancing significantly accelerates internationalization processes of Shanghai based high-tech companies (Chang \& Mao, 2015). Cheng et al. (2020) explain that the professionalization of business intelligence activities and organizational agility, i.e. the adaptivity of knowledge resources to international requirements speed up internationalization processes of Chinese businesses. Neubert \& Van der Krogt (2018a) confirm the relevance of international business intelligence software systems for the internationalization success of lean global start-ups. Hilmerson \& Johanson (2020) evaluate four international knowledge acquisition strategies with businesses from Sweden, Poland and China and find that "grafters" and "pragmatists", i.e. companies that acquire knowledge proactively and do not hesitate to apply their insights internationalize more rapidly than "experiencers" and even "networkers".

\subsubsection{Strategic Planning}

Developing and continuously adjusting a strategic plan for the internationalization process is essential to maximize internationalization speed. Three essential strategic aspects obtain particular consideration in empirical research:

a) The entry mode (Neubert, 2016b; Duet al., 2020, Chahabadi, 2015; Abrahamson, 2018; Clermonts, 2019; Olmos \& Díez-Vial, 2015)

b) The relevance of focal strategies (Neubert, 2017; Neubert \& Vand er Krogt, 2017; Lattemann et al, 2015)

c) Long-term planning (Chahabadi, 2015; Neubert, 2018a; Glodowska et al., 2019; Neubert, 2018a)

To a) In correspondence with the born-global model of internationalization (section 2.4) Abrahamson find a born-global strategy connected to rapid consecutive internationalization of Swedish venture-capital backed start-ups. Conclusively, according to Chahabadi (2015) a high initial internationalization velocity of German enterprises in the renewable energies sector is correlated to higher subsequent internationalization speed. Early cross-listings in different international stock exchanges enable multinationals form different emerging countries to internationalize quickly in spite of high institutional distance (Clermonts, 2019). Du et al. (2020) find that the development status of the target country decides which entry mode maximizes internationalization speed of innovative Chinese businesses: While in developed countries acquisitions are most successful, export strategies excel in emerging markets. Olmos \& Díez-Vial's (2015) study among Spanish wine exporters finds a u-shaped development of export performance for gradual internationalization and an S-shaped performance curve for accelerating internationalization. The study shows that internationalization speed can vary and speed alone is no guarantee for sustainable success, but should be adapted to local market potentials to realize a maximum scope in the long run.

To b) Usually, focal strategies promise successful and rapid entries to new countries and markets. High-tech start-ups from small open economies internationalize early and fast by addressing market niches, where they are the only provider (Neubert, 2017). Interviews with Swiss and Paraguayan high-tech start-ups confirm that these businesses frequently rely on first-mover or pioneer strategies in remote target markets, where they face low entry barriers. This recipe enables fast international expansion (Neubert \& Van der Krogt, 2017). Internationalizing by establishing subsidiaries of a home mother corporation abroad reduces internationalization 
risk and allows high flexibility to adapt to new market conditions early, which speeds up pioneer internationalization projects (Lattemann et al., 2015).

To c) Designing an international growth plan is a sustainable strategy for German renewable energy companies (Chahabadi, 2015). Referring to interviews with senior managers of lean global start-ups, Neubert (2018a) explains that long-term strategic commitment is a common characteristic of most born-global companies. Businesses, however, have to mediate and compromise between local market realities and their long-term strategic goals frequently. The majority of a sample of 355 internationalized Polish businesses see internationalization as an innate strategic orientation, which again contributes to increase internationalization speed and scope (Glodowska et al., 2019).

\subsubsection{Networking}

Networking activity is the most frequently discussed determiner of internationalization speed. Authors assess different network types:

a) Domestic networks (Bemborn, 2018, Genç, 2016; Costa et al., 2015)

b) International networks (Bemborn, 2018; Chang \& Mao, 2015; Falahat, 2018; Lin et al., 2018, Neubert, 2016b; Idris \& Saridakis, 2018; Torkkeli et al., 2019; Chahabadi, 2015, Jain et al, 2019)

c) Combined local and international networking strategies (Neubert, 2017; Neubert \& Van der Krogt, 2020; Ooi \& Richardson, 2020; Prashantam et al., 2019; Vahlne \& Bhatti, 2019) and

d) Virtual networks in digital space (Chang \& Mao, 2015; Mihailova et al., 2015, Wild, 2020, Zahoor \& Al-Tabbaa, 2017).

To a) Early internationalizing companies from Germany rely on strong domestic networks initially to establish first business contracts abroad and learn about foreign market environments (Bemborn, 2018). Alliances with home based non-governmental organizations are an opportunity to develop business relationships with partners in the target countries and contribute to speed up internationalization processes successfully (Genç, 2016). Collaborative networks in the home country provide IT and electronics SME with information on target markets and support decision processes when going abroad (Costa et al., 2015).

To b). International networks are essential to start and establish businesses in the target country and hence are a driver of internationalization speed. Bemborn (2018) find support for this proposition for German businesses and Chang \& Mao (2015) for Shanghai start-ups. In emerging target markets, personal network contacts are particularly valuable to develop outlets (Falahat, 2018). Chinese born-globals from Zhejiang rely on external networking strategies as a foremost entry strategy to Western markets (Lin et al., 2016). Swiss high-tech start-ups pursue the same strategy to set foot outside of the home country (Neubert, 2016b). According to Idris \& Saridakis (2018), formal relationships are more important than informal networks to speed up UK SMEs' export growth. International networking competences mediate potential negative impacts of institutional barriers in the target country for Finnish SME (Torkkeli et al,2019). German businesses from the renewable energy sector internationalize more rapidly and successfully when they dispose of network resources. Jain et al. (2019) provide support that Indian software companies' internationalization speed depends on their ability to develop external linkages and learn from their international network partners.

To c) Few studies assess the combined impact of local and international networks. Neubert (2017) suggests that mixed origin managerial teams accomplish each other to speed up internationalization processes of high-tech startups by developing sustainable marketing strategies for an international environment. Collaboration with a densely knit network of local and international high-tech firms in business clusters enables Paraguayan software companies to establish abroad rapidly (Neubert \& Van der Krogt, 2020). Equally Malayan consultancy firms trust in local business networks, which dispose of international affiliations already to set foot in Western countries (Ooi \& Richardson, 2020). Prashantam et al. (2019) find this development path plausible for India high-tech companies as well. Vahlne \& Bhatti (2019) suggest that beyond peer networks global supplier customer relationships accelerate internationalization processes of SME.

To d) In the age of digitalization, businesses increasingly interact in virtual space and virtual alliances are gaining in importance. Shanghai high-tech companies rely on social networking around the glob to build international alliances (Chang \& Mao, 2015). Equally Russian new ventures use social networking to interconnect with business partners world wide and thus abbreviate lengthy physical internationalization processes. According to Wild (2020), online business hubs have become important platforms for high-tech SME to conquer remote markets and tie research alliances. UK manufacturers utilize their alliance engagement capabilities to co-innovate in virtual development and research environments, with the effect that international 
borders blur and internationalization takes up pace (Zahoo \& al-Tabbaa, 2017)

A third research proposition summarizes the results of section 3.3:

P3: Proactive digital marketing, targeted corporate learning, strategic long-term planning of internationalization processes and networking locally and globally are proven strategies to speed up business internationalization.

Table 3. Content matrix of review results of empirical studies on determiners of internationalization speed

\begin{tabular}{|c|c|c|c|c|c|c|}
\hline \multicolumn{7}{|c|}{ Content matrix - Empirical studies in determiners of internationalization speed (2015- 2020) } \\
\hline & $\begin{array}{l}\text { 1st author, } \\
\text { year }\end{array}$ & $\begin{array}{l}\text { Method, } \\
\text { sample }\end{array}$ & Framing conditions & Business resources & Business activities & $\begin{array}{l}\text { Observed targets \& } \\
\text { effects }\end{array}$ \\
\hline 1 & $\begin{array}{l}\text { Abrahamson, } \\
2018\end{array}$ & $\begin{array}{l}563 \text { VC-backed } \\
\text { startups } \\
\text { Sweden } \\
\text { Regression }\end{array}$ & $\begin{array}{l}\text { - Born-global } \\
\text { firms }\end{array}$ & $\begin{array}{l}-\quad \mathrm{VC} \\
\text { participation }\end{array}$ & & $\begin{array}{l}\text { No significant } \\
\text { impact of VC on } \\
\text { internationalization } \\
\text { speed } \\
\text { born-global are more } \\
\text { frequently backed by } \\
\text { VC }\end{array}$ \\
\hline 2 & Amann, 2016 & $\begin{array}{l}460 \text { SME } \\
\text { Switzerland } \\
\text { regression }\end{array}$ & $\begin{array}{l}-\quad \text { Internationaliz } \\
\text { ation age } \\
\text { - } \quad \text { (early vs late) }\end{array}$ & & & $\begin{array}{l}- \text { High age - } \\
\text { slower } \\
\text { internationalization at } \\
\text { short, mid and } \\
\text { long-term as of } \\
\text { foreign sales and } \\
\text { number of countries }\end{array}$ \\
\hline 3 & $\begin{array}{l}\text { Amorós, } \\
2016\end{array}$ & $\begin{array}{l}374 \\
\text { entrepreneurs } \\
\text { Chile } \\
\text { regression }\end{array}$ & $\begin{array}{l}\text { - extractive } \\
\text { sectors }\end{array}$ & $\begin{array}{l}\text { - Owner-manage } \\
\mathrm{r} \text { high education } \\
\text { - opportunity } \\
\text { orientation }\end{array}$ & $\begin{array}{l}\text { - } \quad \text { new } \\
\text { technology } \\
\text { use }\end{array}$ & $\begin{array}{l}\text { - Determiners } \\
\text { impact Likelihood of } \\
\text { early } \\
\text { internationalization }\end{array}$ \\
\hline 4 & $\begin{array}{l}\text { Bemborn, } \\
2018 \text { (study } \\
\text { 2) }\end{array}$ & $\begin{array}{l}160 \quad \text { German } \\
\text { early } \\
\text { internationalizer } \\
\mathrm{s}\end{array}$ & $\begin{array}{l}\text { - Absorptive } \\
\text { capacity of foreign } \\
\text { markets } \\
\text { ACAP(moderator) }\end{array}$ & & $\begin{array}{l}-\quad \text { Strong } \\
\text { domestic networks } \\
\text { - Close } \\
\text { international network } \\
\text { relationships } \\
\text { - }\end{array}$ & $\begin{array}{l}\text { - High own } \\
\text { networking and loose } \\
\text { foreign networks } \\
\text { improve performance } \\
\text { abroad, }\end{array}$ \\
\hline & $\begin{array}{l}\text { 1st author, } \\
\text { year }\end{array}$ & $\begin{array}{l}\text { Method, } \\
\text { sample }\end{array}$ & Framing conditions & Business resources & Business activities & $\begin{array}{l}\text { Observed targets \& } \\
\text { effects }\end{array}$ \\
\hline 5 & $\begin{array}{l}\text { Bolzani, } \\
2017\end{array}$ & $\begin{array}{l}120 \text { academic } \\
\text { spin-offs Italy }\end{array}$ & & $\begin{array}{l}\text { - Firm equity } \\
-\quad \text { Number of } \\
\text { shareholders }\end{array}$ & & $\begin{array}{l}\text { - Internationaliz } \\
\text { ed spin offs have got } \\
\text { higher equity and a } \\
\text { bit less shareholders }\end{array}$ \\
\hline 6 & Bovina, 2020 & $\begin{array}{l}\text { CEO of } 5 \\
\text { energy sector } \\
\text { businesses }\end{array}$ & & & $\begin{array}{l}\text { - Digital } \\
\text { marketing activity } \\
\text { using } \quad \text { social } \\
\text { networks, } \\
\text { - Structured } \\
\text { digital marketing } \\
\text { strategy }\end{array}$ & $\begin{array}{l}\text { Internationaliz } \\
\text { ation is necessary to } \\
\text { be competitive }\end{array}$ \\
\hline 7 & $\begin{array}{l}\text { Chahabadi, } \\
2015\end{array}$ & $\begin{array}{l}\text { German } \\
\text { renewable } \\
\text { energy industry }\end{array}$ & & $\begin{array}{l}\text { - International } \\
\text { experience of TMT } \\
\text { and firm } \\
\text { - Resources to } \\
\text { establish international } \\
\text { networks }\end{array}$ & $\begin{array}{l}\text { - International } \\
\text { growth strategy } \\
\text { - Initial speed } \\
\text { of } \\
\text { internationalization }\end{array}$ & $\begin{array}{l}\text { - speed of } \\
\text { subsequent } \\
\text { internationalization } \\
\text { diminishes (!) with } \\
\text { international } \\
\text { experience but partly } \\
\text { increases with growth } \\
\text { strategy and initial } \\
\text { speed }\end{array}$ \\
\hline 8 & $\begin{array}{l}\text { Chang \& } \\
\text { Mao, 2015 }\end{array}$ & $\begin{array}{l}57 \text { Shanghai } \\
\text { based high tech }\end{array}$ & & $\begin{array}{l}\text { Entrepreneurial } \\
\text { factors (education, }\end{array}$ & $\begin{array}{l}\text { Experiential learning } \\
\text { Social networks }\end{array}$ & $\begin{array}{lrr}- & \text { Only } & \text { social } \\
\text { networking } & \text { and }\end{array}$ \\
\hline
\end{tabular}




\begin{tabular}{|c|c|c|c|c|c|c|}
\hline & & companies & & $\begin{array}{l}\text { prior experience) } \\
\bullet \quad \text { Market } \\
\text { knowledge }\end{array}$ & $\begin{array}{l}\text { International } \\
\text { alliances }\end{array}$ & $\begin{array}{l}\text { international } \\
\text { alliancing has got a } \\
\text { significant effect }\end{array}$ \\
\hline 9 & $\begin{array}{l}\text { Cheng et al., } \\
2020\end{array}$ & $\begin{array}{lr}258 & \text { Chinese } \\
\text { businesses } & \text { of } \\
\text { Yangtze river } \\
\text { delta }\end{array}$ & $\begin{array}{l}-\quad \text { Cultural } \\
\text { distance }\end{array}$ & & $\begin{array}{l}\text { Business intelligence } \\
\text { Organizational } \\
\text { agility }\end{array}$ & $\begin{array}{l}\text { - Business } \\
\text { intelligence increases } \\
\text { speed of } \\
\text { internationalization } \\
\text { and organizational } \\
\text { agility mediates this } \\
\text { relationship, cultural } \\
\text { distance is a negative } \\
\text { moderator }\end{array}$ \\
\hline $\begin{array}{l}1 \\
0\end{array}$ & $\begin{array}{l}\text { Chiao et al., } \\
2017\end{array}$ & $\begin{array}{l}1362 \text { Taiwanese } \\
\text { manufacturers } \\
\text { Structural } \\
\text { equation }\end{array}$ & & & $\begin{array}{l}-\quad \text { Internal } \\
\text { network resources } \\
\bullet \quad \text { External } \\
\text { network resources }\end{array}$ & $\begin{array}{lr}\text { - Internationaliz } \\
\text { ation } & \text { enhances } \\
\text { performance } & \text { for high } \\
\text { external network } & \text { networces but impairs } \\
\text { resourcer } & \text { internal network } \\
\text { performance } & \end{array}$ \\
\hline $\begin{array}{l}1 \\
1\end{array}$ & $\begin{array}{l}\text { Chun et al., } \\
2020\end{array}$ & $\begin{array}{l}186 \quad \text { Korean } \\
\text { exchange traded } \\
\text { companies } \\
\text { regression }\end{array}$ & $\begin{array}{llll}- & \text { Firm size \& } \\
\text { age } & & & \end{array}$ & $\begin{array}{l}\text { - Prior } \\
\text { experiential } \\
\text { knowledge of CEO \& } \\
\text { TMT } \\
\text { - Technological } \\
\text { knowledge from } \\
\text { patents and R\&D }\end{array}$ & $\begin{array}{l}\text { - Firm } \\
\text { creativity (positive } \\
\text { moderator) }\end{array}$ & $\begin{array}{l}\text { - Patents, TMT } \\
\text { experience and CEO } \\
\text { experience are } \\
\text { positive impacts firm } \\
\text { size is a positive and } \\
\text { age a negative } \\
\text { control, creativity is a } \\
\text { positive moderator }\end{array}$ \\
\hline $\begin{array}{l}1 \\
2\end{array}$ & $\begin{array}{l}\text { Clermonts, } \\
2019\end{array}$ & $\begin{array}{l}197 \text { MNE from } \\
\text { different } \\
\text { emerging } \\
\text { countries } \\
\text { regression }\end{array}$ & $\begin{array}{l}\text { - Institutional } \\
\text { distance (countries' } \\
\text { difference in } \\
\text { institutional } \\
\text { environment) } \\
\text { - Absorptive } \\
\text { capacity }\end{array}$ & & $\begin{array}{l}\text { - Cross-listing } \\
\text { in stock exchanges } \\
\text { of both markets }\end{array}$ & $\begin{array}{l}\text { Institutional } \\
\text { distance }(+) \text { scope } \\
\text { and speed of } \\
\text { internationalization } \\
\text { but negative } \\
\text { moderating impact on } \\
\text { relationship between } \\
\text { absorptive capacity } \\
\text { and } \\
\text { internationalization }\end{array}$ \\
\hline & $\begin{array}{l}\text { 1st author, } \\
\text { year }\end{array}$ & $\begin{array}{l}\text { Method, } \\
\text { sample }\end{array}$ & Framing conditions & Business resources & Business activities & $\begin{array}{l}\text { Observed targets \& } \\
\text { effects }\end{array}$ \\
\hline $\begin{array}{l}1 \\
3\end{array}$ & $\begin{array}{l}\text { Costa et al., } \\
2015\end{array}$ & $\begin{array}{l}\text { SME, } \\
\text { interviews with } \\
\text { CEOs, } \\
\text { IT/electronics }\end{array}$ & & & $\begin{array}{l}\text { - Collaborative } \\
\text { networks provide: } \\
\text { - Intelligent } \\
\text { information } \\
\text { management } \\
\text { - Decision } \\
\text { support }\end{array}$ & $\begin{array}{l}\text { - Collaborative } \\
\text { networks facilitate } \\
\text { internationalization. }\end{array}$ \\
\hline $\begin{array}{l}1 \\
4\end{array}$ & $\begin{array}{l}\text { Du et al., } \\
2020\end{array}$ & $\begin{array}{ll}\text { Innovative } & \\
\text { Chinese } & \\
\text { businesses } & \text { in } \\
\text { developed } & \text { or } \\
\text { emerging } & \\
\text { countries } & \\
\text { regression } & \end{array}$ & $\begin{array}{l}\text { - Development } \\
\text { status of target } \\
\text { country } \\
\text { - Psychic } \\
\text { distance } \\
\text { - Firm age (-) }\end{array}$ & $\begin{array}{l}- \\
\text { experience } \\
\text { - } \quad \text { Multidimensio } \\
\text { nal proximity } \\
\text { - } \quad \text { Internationaliz } \\
\text { ation motivation } \\
-\quad \text { Homogenous } \\
\text { ownership structure } \\
\text { - Innovation } \\
\text { ability }\end{array}$ & - $\quad$ Entry mode & $\begin{array}{l}\text { - Internationaliz } \\
\text { ation mostly in } \\
\text { developing countries } \\
\text { - Entry mode in } \\
\text { developed countries } \\
\text { mostly by acquisition, } \\
\text { in emerging country } \\
\text { mainly by exports }\end{array}$ \\
\hline $\begin{array}{l}1 \\
5\end{array}$ & $\begin{array}{l}\text { Eriksson et } \\
\text { al., } 2015\end{array}$ & $\begin{array}{l}362 \quad \text { service } \\
\text { firms Sweden } \\
\text { Structural } \\
\text { equation }\end{array}$ & & $\begin{array}{l}\text { - Knowledge of } \\
\text { internationalization } \\
\bullet \quad \text { Institutional } \\
\text { knowledge } \\
\text { - Business } \\
\text { knowledge }\end{array}$ & & $\begin{array}{lr}- & \text { Internationaliz } \\
\text { ation } & \text { knowledge } \\
\text { impacts } & \text { institutional } \\
\text { and } & \text { business } \\
\text { knowledge } & \text { which } \\
\text { again diminish cost of }\end{array}$ \\
\hline
\end{tabular}




\begin{tabular}{|c|c|c|c|c|c|c|}
\hline $\begin{array}{l}1 \\
6\end{array}$ & Falahat, 2018 & $\begin{array}{l}1001 \\
\text { internationalize } \\
\mathrm{d} \text { firms in } \\
\text { emerging } \\
\text { market }\end{array}$ & & $\begin{array}{l}\text { - Entrepreneurial } \\
\text { orientation }\end{array}$ & $\begin{array}{l}\text { - Marketing } \\
\text { strategy } \\
\text { - Institutional } \\
\text { network and } \\
\text { business network } \\
\text { (contacts to persons) }\end{array}$ & $\begin{array}{l}\text { internationalization } \\
\text { - Marketing } \\
\text { strategy mediates the } \\
\text { impact of EO and } \\
\text { networking capability } \\
\text { on foreign market } \\
\text { performance } \\
\text { m EO and } \\
\text { marketing strategy } \\
\text { impact foreign market } \\
\text { performance }\end{array}$ \\
\hline $\begin{array}{l}1 \\
7\end{array}$ & Genç, 2016 & $\begin{array}{l}\text { No empirical } \\
\text { model test }\end{array}$ & & $\begin{array}{l}\text { - International } \\
\text { experience } \\
\text { (moderator) }\end{array}$ & $\begin{array}{l}\text { - Alliances with } \\
\text { home-based NGO }\end{array}$ & $\begin{array}{l}\text { - Alliances } \\
\text { increase } \\
\text { internationalization } \\
\text { speed and } \\
\text { performance, } \\
\text { entrepreneurial } \\
\text { experience mediates. }\end{array}$ \\
\hline $\begin{array}{l}1 \\
8\end{array}$ & $\begin{array}{l}\text { Glodowska et } \\
\text { al., } 2019\end{array}$ & $\begin{array}{l}355 \\
\text { internationalize } \\
\mathrm{d} \quad \text { Polish } \\
\text { businesses } \\
\text { T-test, ANOVA }\end{array}$ & $\begin{array}{l}\text { - Number of } \\
\text { employees }\end{array}$ & & $\begin{array}{l}\text { - International } \\
\text { strategy as a } \\
\text { planning instrument }\end{array}$ & $\begin{array}{l}\text { - Strategy } \\
\text { increases speed and } \\
\text { scope } \\
\text { internationalization of }\end{array}$ \\
\hline $\begin{array}{l}1 \\
9\end{array}$ & $\begin{array}{l}\text { Hilmerson \& } \\
\text { Johanson, } \\
2015\end{array}$ & $\begin{array}{l}183 \text { SME from } \\
\text { Southern } \\
\text { Sweden }\end{array}$ & $\begin{array}{l}\text { Breadth of } \\
\text { international markets }\end{array}$ & $\begin{array}{l}\text { - Commitment } \\
\text { to international } \\
\text { resources }\end{array}$ & & $\begin{array}{l}\text { Impact of } \\
\text { internationalization } \\
\text { speed on performance } \\
\text { - Internationaliz } \\
\text { ation breadth has } \\
\text { positive curvilinear } \\
\text { effect on performance } \\
\text { in Commitment } \\
\text { in international } \\
\text { resources har has } \\
\text { negative curvilinear } \\
\text { performance effect }\end{array}$ \\
\hline & $\begin{array}{l}\text { 1st author, } \\
\text { year }\end{array}$ & $\begin{array}{l}\text { Method, } \\
\text { sample }\end{array}$ & Framing conditions & Business resources & Business activities & $\begin{array}{l}\text { Observed targets \& } \\
\text { effects }\end{array}$ \\
\hline $\begin{array}{l}2 \\
0\end{array}$ & $\begin{array}{l}\text { Hilmerson \& } \\
\text { Johanson, } \\
2020\end{array}$ & $\begin{array}{l}618 \text { SME form } \\
\text { Sweden, Poland } \\
\text { \& China } \\
\text { T-test }\end{array}$ & & & $\begin{array}{l}\text { - } \quad 4 \text { international } \\
\text { knowledge } \\
\text { acquisition } \\
\text { strategies: }\end{array}$ & $\begin{array}{l}\text { - Grafters \& } \\
\text { Pragmatists } \\
\text { internationalize faster } \\
\text { than Experiencers and } \\
\text { Networkers } \\
\text { - Speed } \\
\text { capability of } \\
\text { development has U } \\
\text { shaped effect on } \\
\text { speed of } \\
\text { internationalization }\end{array}$ \\
\hline $\begin{array}{l}2 \\
1\end{array}$ & $\begin{array}{l}\text { Hsieh et al., } \\
2019\end{array}$ & $\begin{array}{l}180 \quad \text { SME } \\
\text { clothing, } \\
\text { software and } \\
\text { biotechnology } \\
\text { industries in six } \\
\text { economies }\end{array}$ & & $\begin{array}{l}\text { - Entrepreneurial } \\
\text { characteristics } \\
\text { (experience \& } \\
\text { rationales) }\end{array}$ & $\begin{array}{l}\text { - innovation } \\
\text { strategy }\end{array}$ & $\begin{array}{l}\text { - Dimensions of } \\
\text { internationalization : } \\
\text { earliness, speed of } \\
\text { deepening, speed of } \\
\text { geographic } \\
\text { diversification: } \\
\text { different determiners } \\
\text { impact }\end{array}$ \\
\hline $\begin{array}{l}2 \\
2\end{array}$ & $\begin{array}{l}\text { Hutzschenreu } \\
\text { ter et al., } \\
2016\end{array}$ & $\begin{array}{l}788 \text { Business } \\
\text { units of } 90 \\
\text { established } \\
\text { German MNE } \\
\text { regression }\end{array}$ & $\begin{array}{l}\text { - Corporate } \\
\text { environment of parent } \\
\text { MNC }\end{array}$ & $\begin{array}{l}-\quad \text { Business } \\
\text { knowledge } \\
\text { accumulation } \\
\text { - Internationaliz } \\
\text { ation knowledge } \\
-\quad \text { Temporal order }\end{array}$ & & $\begin{array}{lr}- & \text { Internationaliz } \\
\text { ation speed increases } \\
\text { with } \\
\text { relatedness parent } \\
\text { reliance on indirect } \\
\text { learning form parent }\end{array}$ \\
\hline
\end{tabular}




\begin{tabular}{|c|c|c|c|c|c|c|}
\hline & & & & $\begin{array}{l}\text { of knowledge } \\
\text { acquisition }\end{array}$ & & $\begin{array}{l}\text { - Positive effect } \\
\text { of direct leaning of } \\
\text { internationalization } \\
\text { knowledge }\end{array}$ \\
\hline $\begin{array}{l}2 \\
3\end{array}$ & $\begin{array}{l}\text { Idris } \quad \& \\
\text { Saridakis, } \\
2018\end{array}$ & $\begin{array}{l}15,502 \text { CO of } \\
\text { UK SME (up to } \\
249 \text { employees), } \\
\text { Regression }\end{array}$ & Firm size & & $\begin{array}{l}\text { - Local formal } \\
\text { and informal } \\
\text { interpersonal } \\
\text { networks }\end{array}$ & $\begin{array}{l}\text { - Formal } \\
\text { interpersonal } \\
\text { networks increase } \\
\text { likelihood of } \\
\text { exporting } \\
\text { - Informal } \\
\text { (family) networks are } \\
\text { less important }\end{array}$ \\
\hline 2 & Ivanauskiene & 53 SME in & $\bullet$ & Orientation & e-marketing & E-marketing \\
\hline 4 & et al. , 2015 & Baltic countries & & $\begin{array}{l}\text { towards } \\
\text { technologies }\end{array}$ & $\begin{array}{l}\text { strategy } \\
\text { (insignificant) } \\
\text { design web site }\end{array}$ & $\begin{array}{l}\text { speeds up } \\
\text { internationalization }\end{array}$ \\
\hline $\begin{array}{l}2 \\
5\end{array}$ & $\begin{array}{l}\text { Jain et al., } \\
2019\end{array}$ & $\begin{array}{l}\text { Indian software } \\
\text { companies } \\
\text { Longitudinal } \\
\text { dataset }\end{array}$ & $\begin{array}{l}\text { - Firm } \\
\text { (Employees) }\end{array}$ & $\begin{array}{l}\text { - } \quad \text { External } \\
\text { linkage capabilities } \\
\text { - Internal } \\
\text { linkage capabilities } \\
\text { - Leveraging } \\
\text { capabilities } \\
\text { - Learning } \\
\text { capabilities } \\
\text { - Learning } \\
\text { orientation } \\
\text { capabilities }\end{array}$ & $\bullet$ & $\begin{array}{l}\text { - Internal and } \\
\text { external linkage and } \\
\text { learning capabilities } \\
\text { increase } \\
\text { internationalization } \\
\text { speed }\end{array}$ \\
\hline $\begin{array}{l}2 \\
6\end{array}$ & $\begin{array}{l}\text { Lattemann et } \\
\text { al., } 2015\end{array}$ & $\begin{array}{l}\text { Internationalizin } \\
\text { g Chinese MNE }\end{array}$ & $\begin{array}{ll}- & \text { Firm age (-) } \\
\text { - } & \text { Firm size }(+)\end{array}$ & & $\begin{array}{l}\text { - Speed of } \\
\text { subsidiary expansion } \\
\text { - Speed } \quad \text { of } \\
\text { geographic } \\
\text { expansion }\end{array}$ & $\begin{array}{l}\text { - Speed of } \\
\text { subsidiary expansion } \\
\text { impacts performance } \\
\text { in emerging countries } \\
\text { - Speed of } \\
\text { geographic expansion } \\
\text { determines success in } \\
\text { developed countries }\end{array}$ \\
\hline & $\begin{array}{l}\text { 1st author, } \\
\text { year }\end{array}$ & $\begin{array}{l}\text { Method, } \\
\text { sample }\end{array}$ & Framing conditions & Business resources & Business activities & $\begin{array}{l}\text { Observed targets \& } \\
\text { effects }\end{array}$ \\
\hline $\begin{array}{l}2 \\
7\end{array}$ & $\begin{array}{l}\text { Lin et al., } \\
2016\end{array}$ & $\begin{array}{l}\text { Chinese } \\
\text { born-global } \\
\text { SEME } \\
\text { Zhejiang }\end{array}$ & $\bullet$ & $\begin{array}{ll}\text { - } \quad \text { Managerial } & \\
\text { orientation } & \& \\
\text { expertise } & \end{array}$ & $\begin{array}{l}\text { - External } \\
\text { networking }\end{array}$ & $\begin{array}{l}\text { - Both factors } \\
\text { contribute to rapid } \\
\text { internationalization }\end{array}$ \\
\hline $\begin{array}{l}2 \\
8\end{array}$ & $\begin{array}{l}\text { Mihailova et } \\
\text { al., } 2015\end{array}$ & $\begin{array}{l}120 \quad \text { Russian } \\
\text { new ventures } \\
\text { regression }\end{array}$ & $\begin{array}{l}\text { - Institutional } \\
\text { factors: regulation of } \\
\text { environment, norms } \\
\text { for international } \\
\text { expansion } \\
\text { - Industry } \\
\text { factors: technology } \\
\text { intensity } \\
\text { - Age, firm size, } \\
\text { market size }\end{array}$ & $\begin{array}{l}\text { - Entrepreneurial } \\
\text { experience in } \\
\text { internationalization } \\
\text { - Product } \\
\text { innovativeness }\end{array}$ & $\begin{array}{l}\text { - Social } \\
\text { network engagement }\end{array}$ & $\begin{array}{l}\text { - Social } \\
\text { networking, industry } \\
\text { technological } \\
\text { intensity, regulated } \\
\text { institutional } \\
\text { environment \& } \\
\text { entrepreneurial } \\
\text { experience increase } \\
\text { internationalization } \\
\text { degree } 6 \text { scope }\end{array}$ \\
\hline $\begin{array}{l}2 \\
9\end{array}$ & $\begin{array}{l}\text { Mohr et al., } \\
2018\end{array}$ & $\begin{array}{l}9,000 \text { Retail } \\
\text { SME in } 211 \\
\text { countries }\end{array}$ & & $\begin{array}{l}\text { - Managerial } \\
\text { resources by } \\
\text { geographical } \\
\text { fungibility } \\
\text { - International } \\
\text { experience }\end{array}$ & & $\begin{array}{l}\text { - International } \\
\text { divestment after rapid } \\
\text { expansion is } \\
\text { moderated } \\
\text { inter-regional } \\
\text { concentration and } \\
\text { international } \\
\text { experience }\end{array}$ \\
\hline $\begin{array}{l}3 \\
0\end{array}$ & $\begin{array}{l}\text { Neubert, } \\
2016 \mathrm{a}\end{array}$ & $\begin{array}{lr}20 & \text { Swiss } \\
\text { high-tech } & \text { start }\end{array}$ & $\begin{array}{l}\text { - } \quad \text { Requirement of } \\
\text { self-reliant financing }\end{array}$ & $\begin{array}{l}\text { - Disruptive } \\
\text { technologies find }\end{array}$ & & $\begin{array}{l}\text { - } \quad \text { Businesses } \\
\text { survival depends on }\end{array}$ \\
\hline
\end{tabular}




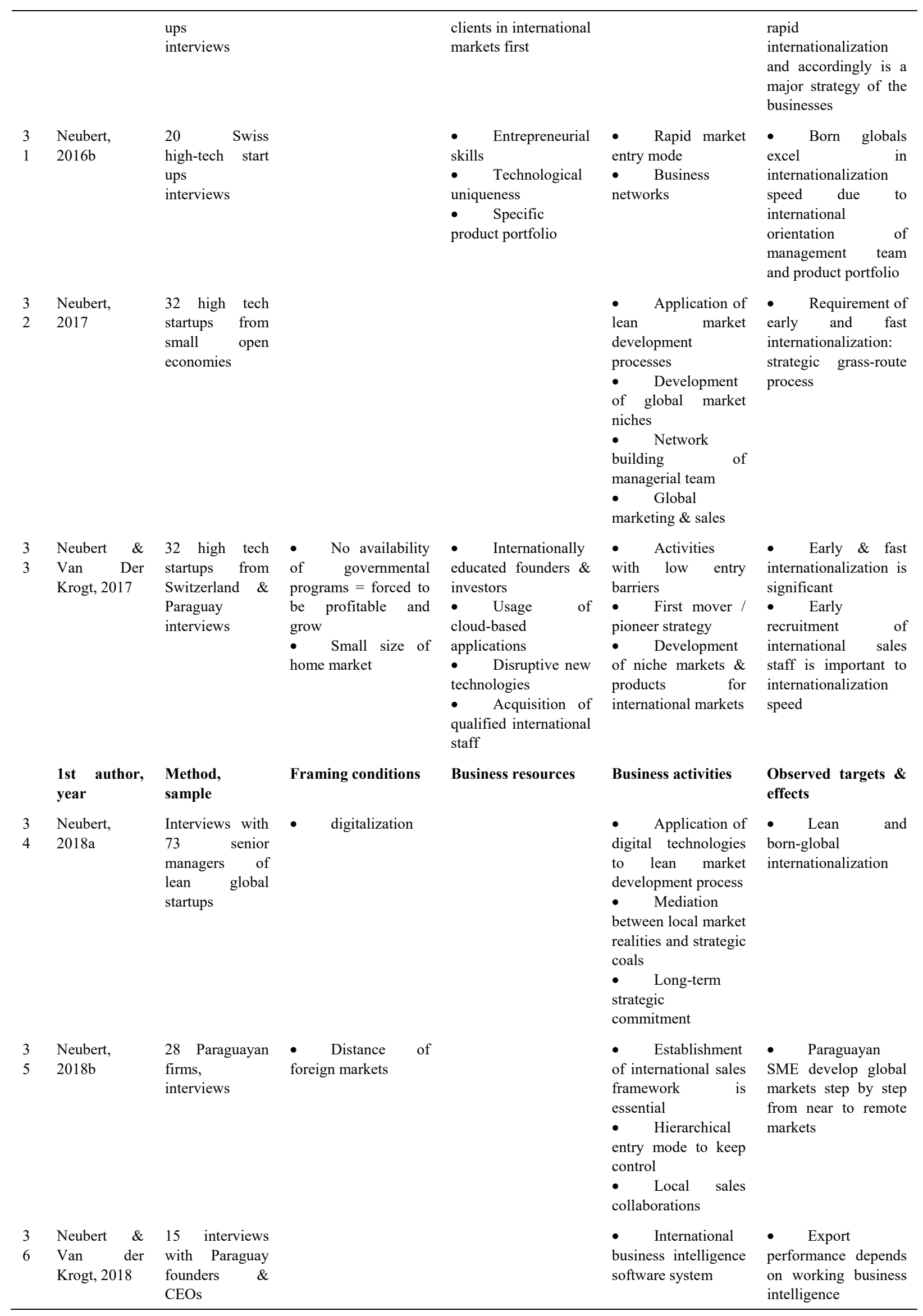




\begin{tabular}{|c|c|c|c|c|c|c|}
\hline $\begin{array}{l}3 \\
7\end{array}$ & $\begin{array}{l}\text { Neubert \& } \\
\text { Van der } \\
\text { Krogt, } 2020\end{array}$ & $\begin{array}{l}45 \text { Paraguayan } \\
\text { software firms }\end{array}$ & & $\begin{array}{l}-\quad \text { Decision } \\
\text { makers characteristics }\end{array}$ & $\begin{array}{lr}\text { - } & \text { Collaboration } \\
\text { with } & \text { further } \\
\text { international } & \text { high } \\
\text { tech firms } & \end{array}$ & $\begin{array}{l}\text { - Both factors } \\
\text { impact } \\
\text { internationalization } \\
\text { speed }\end{array}$ \\
\hline $\begin{array}{l}3 \\
8\end{array}$ & $\begin{array}{l}\text { Olmos \& } \\
\text { Díez-Vial, } \\
2015\end{array}$ & $\begin{array}{l}\text { Spanish Wine } \\
\text { exporting } \\
\text { companies }\end{array}$ & & & $\begin{array}{l}\text { - Export } \\
\text { intensity }\end{array}$ & $\begin{array}{l}\text { - Export } \\
\text { performance is } \\
\text { u-shaped with gradual } \\
\text { internationalization } \\
\text { and } \mathrm{S} \text { shaped for } \\
\text { accelerating } \\
\text { internationalization }\end{array}$ \\
\hline $\begin{array}{l}3 \\
9\end{array}$ & $\begin{array}{l}\text { Ooi \& } \\
\text { Richardson, } \\
2020\end{array}$ & $\begin{array}{l}31 \quad \text { interviews } \\
\text { with } 8 \text { Malayan } \\
\text { consultancy } \\
\text { firms }\end{array}$ & $\begin{array}{l}\text { - Psychic } \\
\text { distance }\end{array}$ & $\begin{array}{l}\text { - } \quad \text { Business } \\
\text { capabilities }\end{array}$ & $\begin{array}{l}\text { - Business } \\
\text { network }\end{array}$ & $\begin{array}{l}\text { - All three } \\
\text { factors determine } \\
\text { openness and speed } \\
\text { of internationalization }\end{array}$ \\
\hline $\begin{array}{l}4 \\
0\end{array}$ & $\begin{array}{l}\text { Prashantam } \\
\text { et al., } 2019\end{array}$ & $\begin{array}{l}\text { No empirical } \\
\text { support }\end{array}$ & & & $\begin{array}{l}\text { - Effectual vs } \\
\text { non-effectual } \\
\text { network building }\end{array}$ & $\begin{array}{l}\text { - Network } \\
\text { building increases } \\
\text { entry speed but }\end{array}$ \\
\hline $\begin{array}{l}4 \\
1\end{array}$ & $\begin{array}{l}\text { Rialp-Criado } \\
\& \quad \text { Rialp, } \\
2020\end{array}$ & $\begin{array}{l}\text { Energy } \\
\text { providers }\end{array}$ & $\begin{array}{l}\text { - } \quad \text { Industry (B2B } \\
\text { or } \mathrm{B} 2 \mathrm{C}) \\
\text { - } \quad \text { Export } \\
\text { intensity of industry } \\
\text { - } \quad \text { Not: firm size }\end{array}$ & & $\begin{array}{ll}-\quad \text { Speed } & \text { of } \\
\text { social media use }\end{array}$ & $\begin{array}{l}\text { - } \quad \text { Speed of SM } \\
\text { use increases speed of } \\
\text { internationalization }\end{array}$ \\
\hline $\begin{array}{l}4 \\
2\end{array}$ & $\begin{array}{l}\text { Saghebi et } \\
\text { al., } 2019\end{array}$ & $\begin{array}{l}320 \quad \text { Iranian } \\
\text { SME } \\
\text { Structural } \\
\text { equation }\end{array}$ & & $\begin{array}{l}\text { - Managers } \\
\text { entrepreneurial } \\
\text { perception }(\mathrm{EO})\end{array}$ & & $\begin{array}{l}\text { - Internationaliza } \\
\text { tion speed depends on } \\
\text { EO }\end{array}$ \\
\hline & $\begin{array}{l}\text { 1st author, } \\
\text { year }\end{array}$ & $\begin{array}{l}\text { Method, } \\
\text { sample }\end{array}$ & Framing conditions & Business resources & Business activities & $\begin{array}{l}-\quad \text { Observed } \\
\text { targets \& effects }\end{array}$ \\
\hline $\begin{array}{l}4 \\
3\end{array}$ & $\begin{array}{l}\text { Schu et al., } \\
2016\end{array}$ & $\begin{array}{l}150 \quad \text { online } \\
\text { retailers in } 47 \\
\text { countries, Cox } \\
\text { variation }\end{array}$ & $\begin{array}{l}\text { - Distance and } \\
\text { diversity in country } \\
\text { portfolio }\end{array}$ & $\begin{array}{l}\text { - } \quad \text { Imitability of } \\
\text { shop } \\
\text { - } \quad \text { Venture capital } \\
\text { availability }\end{array}$ & & $\begin{array}{l}\text { - Curvilinear } \\
\text { effect of online shop } \\
\text { imitability diversity } \\
\text { and scope of portfolio } \\
\text { and linear effect of } \\
\text { distance of remote } \\
\text { markets on length and } \\
\text { next step of } \\
\text { internationalization }\end{array}$ \\
\hline $\begin{array}{l}4 \\
4\end{array}$ & $\begin{array}{l}\text { Torkkeli et } \\
\text { al., } 2019\end{array}$ & $\begin{array}{l}119 \\
\text { international } \\
\text { Finnish SME } \\
\text { regression }\end{array}$ & $\begin{array}{ll}\text { - } & \text { Institutional } \\
\text { drivers/ barriers } \\
\text { - } & \text { Industry sector } \\
\text { - } & \text { size }\end{array}$ & & $\begin{array}{l}\text { - Networking } \\
\text { competence mediate } \\
\text { impact of } \\
\text { institutional factors }\end{array}$ & $\begin{array}{l}\text { - Institutional } \\
\text { factors are dominant } \\
\text { determiners of } \\
\text { international } \\
\text { performance }\end{array}$ \\
\hline $\begin{array}{l}4 \\
5\end{array}$ & $\begin{array}{l}\text { Vahlne \& } \\
\text { Bhatti, } 2019\end{array}$ & $\begin{array}{l}\text { Longitudinal } \\
\text { study }\end{array}$ & & $\begin{array}{l}\text { - } \quad \text { Knowledge } \\
\text { development } \\
\text { - } \quad \text { commitment }\end{array}$ & $\begin{array}{l}\text { - Supplier-custo } \\
\text { mer relationships } \\
\text { - Opportunity } \\
\text { identification }\end{array}$ & $\begin{array}{l}\text { - Dynamic } \\
\text { capabilities enable } \\
\text { businesses } \\
\text { internationalize } \\
\text { successfully }\end{array}$ \\
\hline $\begin{array}{l}4 \\
6\end{array}$ & Vlacic, 2018 & $\begin{array}{l}134 \quad \text { Future } \\
\text { entrepreneurs } \\
\text { Structural } \\
\text { equation }\end{array}$ & & $\begin{array}{l}\text { - Managerial } \\
\text { cognitive reasoning } \\
\text { - } \quad \text { Managerial } \\
\text { experience }\end{array}$ & $\bullet$ & $\begin{array}{l}\text { - Both factors } \\
\text { impact } \\
\text { internationalization } \\
\text { intention }\end{array}$ \\
\hline $\begin{array}{l}4 \\
7\end{array}$ & $\begin{array}{l}\text { Wach et al., } \\
2018\end{array}$ & $\begin{array}{l}355 \quad \text { Polish } \\
\text { businesses } \\
\text { regression }\end{array}$ & & $\begin{array}{l}\text { - Entrepreneurial } \\
\text { orientation } \\
\text { - Market, } \\
\text { network and } \\
\text { Entrepreneurial } \\
\text { knowledge }\end{array}$ & $\begin{array}{l}\text { - Knowledge } \\
\text { utilization. }\end{array}$ & $\begin{array}{l}\text { - EO enhances } \\
\text { knowledge use in } \\
\text { internationalization } \\
\text { scope } \\
\text { internationalization } \\
\text { benefits of EO, } \\
\text { particularly } \\
\text { risk-taking }\end{array}$ \\
\hline
\end{tabular}




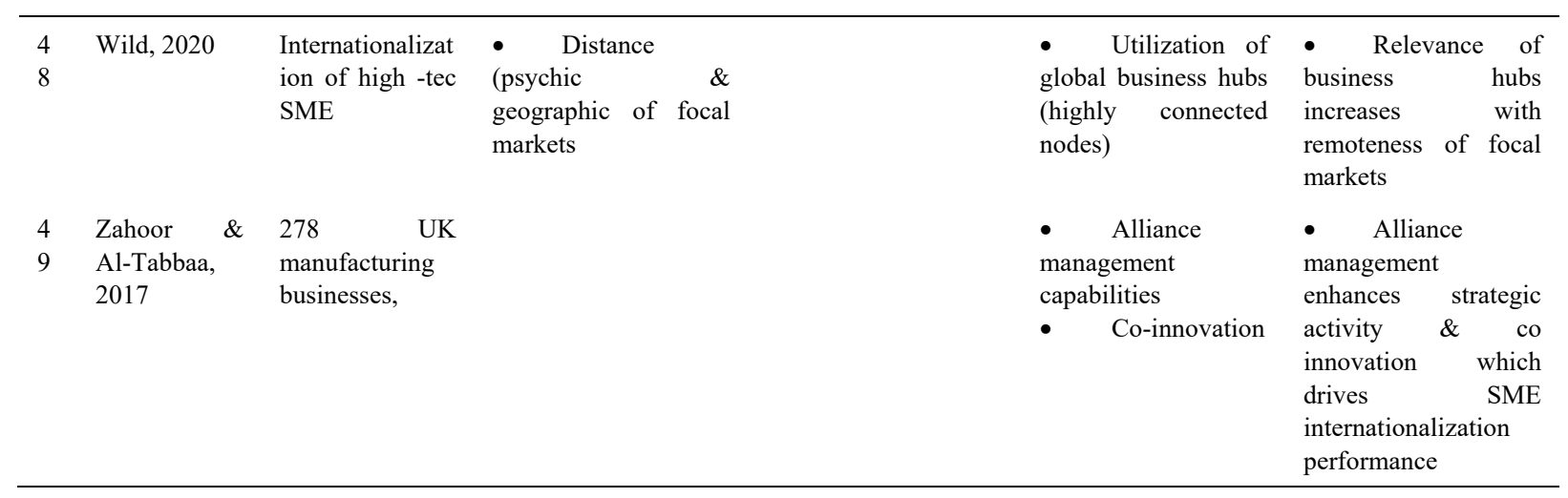

Table 4. Concept matrix of categories of determiners of internationalization speed

\begin{tabular}{|c|c|c|c|}
\hline \multicolumn{4}{|c|}{ Classification of empirical research in determiners of internationalization speed (2015- 2020) } \\
\hline Category & Determiners & Observed effects & Author, year \\
\hline \multicolumn{4}{|l|}{$\underline{\text { Framing conditions }}$} \\
\hline \multirow[t]{4}{*}{ Sectoral framing conditions } & \multirow[t]{3}{*}{ Business sector } & Extractive $(+)$ & Amorós, 2016 \\
\hline & & Technology intensity $(+)$ & Mihailova et al., 2015 \\
\hline & & $\begin{array}{l}\text { Industry (B2B or B2C) } \\
\text { Export intensity }\end{array}$ & $\begin{array}{l}\text { Rialp-Criado \& Rialp, } \\
2020\end{array}$ \\
\hline & Digitalization & Application of digital technologies in sector $(+)$ & Neubert, 2018 a \\
\hline \multirow{5}{*}{$\begin{array}{l}\text { Framing conditions } \\
\text { home market }\end{array}$} & \multirow{5}{*}{ Funding resources } & Necessity of self-financing $(+)$ & Neubert, 2016a \\
\hline & & No government programs $(+)$ & $\begin{array}{l}\text { Neubert \& Van De Krogt, } \\
2017\end{array}$ \\
\hline & & Small size of home market & $\begin{array}{l}\text { Neubert \& Van De Krogt, } \\
2017 \\
\text { Mihailova et al., } 2015\end{array}$ \\
\hline & & Institutional barriers/drivers in home country & Torkkeli et al., 2019 \\
\hline & & $\begin{array}{l}\text { institutional environment in home market } \\
\text { regulation of environment, norms for international } \\
\text { expansion }\end{array}$ & Mihailova et al., 2020 \\
\hline \multirow[t]{9}{*}{$\begin{array}{l}\text { Framing conditions } \\
\text { target countries }\end{array}$} & \multirow[t]{6}{*}{$\begin{array}{l}\text { Distance } \\
\text { distance }\end{array}$} & Cultural distance (-) & $\begin{array}{l}\text { Cheng et al., } 2020 \\
\text { Wild, } 2020\end{array}$ \\
\hline & & Physical distance (-) & $\begin{array}{l}\text { Neubert, 2018b } \\
\text { Wild, } 2020\end{array}$ \\
\hline & & Psychic distance (-) & $\begin{array}{l}\text { Ooi \& Richardson, } 2020 \\
\text { Wild } 2020\end{array}$ \\
\hline & & Institutional distance (-) & Clermonts, 2019 \\
\hline & & Distance \& diversity of country portfolio & Schu et al., 2016 \\
\hline & & Corporate environment of parent $\mathrm{MNC}(+)$ & $\begin{array}{l}\text { Hutzschenreuter et al., } \\
2016\end{array}$ \\
\hline & \multirow[t]{3}{*}{$\begin{array}{l}\text { Conditions } \\
\text { market }\end{array}$} & Absorptive capacity of foreign markets $(+)$ & $\begin{array}{l}\text { Bemborn, } 2018 \\
\text { Clermonts, } 2019\end{array}$ \\
\hline & & Development status of target country & Du et al. (2020) \\
\hline & & Breadth of international markets & $\begin{array}{l}\text { Hilmerson \& Johanson, } \\
2015\end{array}$ \\
\hline
\end{tabular}




\begin{tabular}{|c|c|c|c|}
\hline Category & Determiners & Observed effects & Author, year \\
\hline \multicolumn{4}{|l|}{$\underline{\text { Business resources }}$} \\
\hline \multirow[t]{3}{*}{$\begin{array}{l}\text { Framing conditions } \\
\text { company level }\end{array}$} & $\begin{array}{l}\text { Age } \\
\text { internationalization (-) }\end{array}$ & Int. Age (-) & $\begin{array}{l}\text { Amann, } 2016 \\
\text { Chun, } 2020 \\
\text { Du et al., } 2020 \\
\text { Mihailova et al., } 2015 \\
\text { Lattemann et al., } 2015\end{array}$ \\
\hline & Firm size & Firm size $(+)$ & $\begin{array}{l}\text { Chun, } 2020 \\
\text { Idris \& Saridakis, } 2018 \\
\text { Jain et al, } 2019 \\
\text { Lattemann et al., } 2015 \\
\text { Mihailova et al., } 2015 \\
\text { Rialp-Criado \& Rialp, } \\
2020 \text { (not) }\end{array}$ \\
\hline & & Number of employees $(+)$ & Glodwska et al., 2019 \\
\hline \multirow[t]{13}{*}{$\begin{array}{l}\text { Owner manager } \\
\text { resources }\end{array}$} & Owner/ manager training & Education $(+)$ & $\begin{array}{l}\text { Amorós, } 2016 \\
\text { Chang \& Mao, } 2015\end{array}$ \\
\hline & & Internationally educated founders \& investors & $\begin{array}{l}\text { Neubert \& Van Der } \\
\text { Krogt, 2017 }\end{array}$ \\
\hline & & $\begin{array}{l}\text { Managerial cognitive reasoning } \\
\text { Managerial experience }\end{array}$ & Vlacic, 2018 \\
\hline & Human resources & qualified international staff & $\begin{array}{l}\text { Neubert \& Van Der } \\
\text { Krogt, 2017 }\end{array}$ \\
\hline & & Managerial resources by geographical fungibility & Mohr et al., 2018 \\
\hline & Experience & International experience of TMT/CEO & $\begin{array}{l}\text { Chahabadi, } 2015 \\
\text { Lin et al. } 2016\end{array}$ \\
\hline & & Prior international experience & $\begin{array}{l}\text { Chang \& Mao, } 2015 \\
\text { Chun et al., } 2020 \\
\text { Du et al. } 2020 \\
\text { Mihailova et al., } 2015\end{array}$ \\
\hline & & International experience & $\begin{array}{l}\text { Genç, } 2016 \\
\text { Mohr et al., } 2018\end{array}$ \\
\hline & Entrepreneurship & $\begin{array}{l}\text { Entrepreneurial characteristics } \quad \text { (experience } \\
\text { rationales) }\end{array}$ & Hsieh et al., 2019 \\
\hline & & Entrepreneurial orientation & $\begin{array}{l}\text { Fahalat, } 2018 \\
\text { Lin et al., } 2016 \\
\text { Saghebi et al., } 2019 \\
\text { Wach et al., } 2018\end{array}$ \\
\hline & Owner manager attitude & Opportunity orientation $(+)$ & Amorós, 2016 \\
\hline & & Entrepreneurial skills & Neubert, 2016b \\
\hline & & Decision makers characteristics & $\begin{array}{l}\text { Neubert \& Van der Krogt, } \\
2020\end{array}$ \\
\hline Knowledge resources & $\begin{array}{l}\text { Knowledge of target } \\
\text { market }\end{array}$ & Market knowledge & Chang \& Mao, 2015 \\
\hline \multirow[t]{6}{*}{ Category } & Determiners & Observed effects & Author, year \\
\hline & & Market, network and Entrepreneurial knowledge & Wach et al., 2018 \\
\hline & Innovation knowledge & Technological knowledge from patents and $\mathrm{R} \& \mathrm{D}$ & Chun et al., 2020 \\
\hline & & Innovation ability & Du et al., 2020 \\
\hline & & Orientation towards new technologies & Ivanauskiene et al. , 2015 \\
\hline & & Knowledge development & Vahlne \& Bhatti, 2019 \\
\hline
\end{tabular}




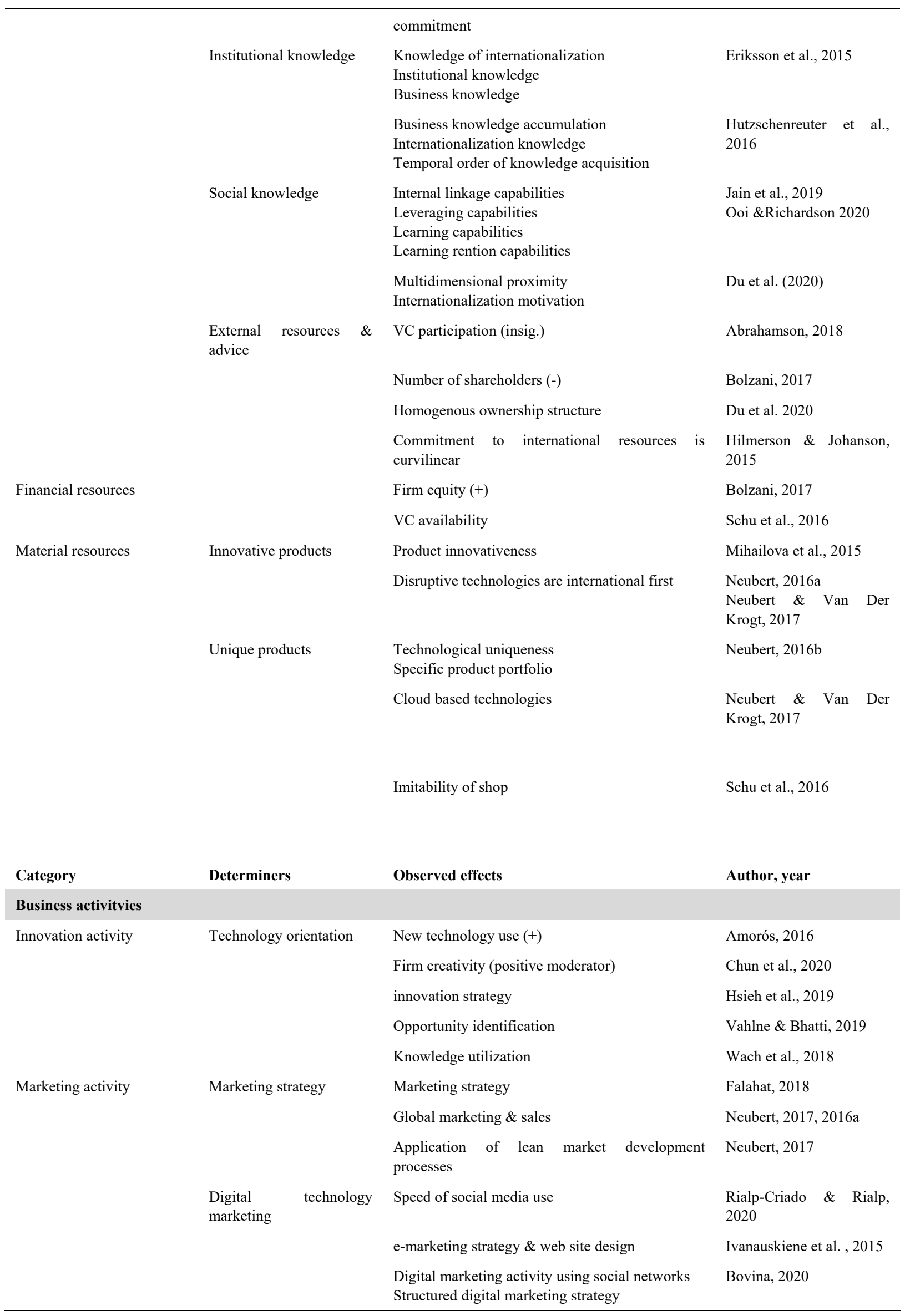




\begin{tabular}{|c|c|c|c|}
\hline & & $\begin{array}{l}\text { Application of digital technologies to lean market } \\
\text { development process }\end{array}$ & Neubert, 2018b \\
\hline & & $\begin{array}{l}\text { Establishment of international sales framework is } \\
\text { essential } \\
\text { Local sales collaborations }\end{array}$ & Neubert, 2018b \\
\hline \multirow[t]{4}{*}{ Learning } & & Experiential learning & $\begin{array}{l}\text { Chang \& Mao, } 2015 \\
\text { Ooi \&Richardson } 2020\end{array}$ \\
\hline & & $\begin{array}{l}\text { Business intelligence } \\
\text { Organizational agility }\end{array}$ & Cheng et al., 2020 \\
\hline & & $\begin{array}{l}\text { International business intelligence software } \\
\text { system }\end{array}$ & $\begin{array}{l}\text { Neubert \& Van der Krogt, } \\
2018\end{array}$ \\
\hline & & 4 international knowledge acquisition strategies & $\begin{array}{l}\text { Hilmerson \& Johanson, } \\
2020\end{array}$ \\
\hline \multirow[t]{6}{*}{ Strategic plannning } & Entry mode & Rapid market entry mode & Neubert, 2016b \\
\hline & & Entry mode & Du et al., 2020 \\
\hline & & Initial speed of internationalization & Chahabadi, 2015 \\
\hline & & Born-global orientation $(+)$ & Abrahamson, 2018 \\
\hline & & Cross-listing in stock exchanges of both markets & Clermonts, 2019 \\
\hline & & Export intensity & Olmos \& Díez-Vial, 2015 \\
\hline \multirow[t]{10}{*}{ Category } & Determiners & Observed effects & Author, year \\
\hline & Focal strategies & Development of global market niches & Neubert, 2017 \\
\hline & & $\begin{array}{l}\text { Development of niche markets \& products for } \\
\text { international markets }\end{array}$ & $\begin{array}{l}\text { Neubert \& Van Der } \\
\text { Krogt, } 2017\end{array}$ \\
\hline & & Activities with low entry barriers & $\begin{array}{l}\text { Neubert \& Van Der } \\
\text { Krogt, } 2017\end{array}$ \\
\hline & & First mover / pioneer strategy & $\begin{array}{l}\text { Neubert \& Van Der } \\
\text { Krogt, 2017 }\end{array}$ \\
\hline & & $\begin{array}{l}\text { Speed of subsidiary expansion } \\
\text { Speed of geographic expansion }\end{array}$ & Lattemann et al., 2015 \\
\hline & Long-term planning & International growth strategy & Chahabadi, 2015 \\
\hline & & $\begin{array}{l}\text { Long-term strategic commitment } \\
\text { Hierarchical entry mode to keep control }\end{array}$ & Neubert, 2018a \\
\hline & & International strategy as a planning instrument & Glodowska et al., 2019 \\
\hline & & $\begin{array}{l}\text { Mediation between local market realities and } \\
\text { strategic goals }\end{array}$ & Neubert, 2018a \\
\hline \multirow[t]{8}{*}{ Network relationships } & Domestic networks & Strong domestic networks & Bemborn, 2018 \\
\hline & & Alliances with home-based NGO & Genç, 2016 \\
\hline & & $\begin{array}{l}\text { Internal network resources } \\
\text { External network resources }\end{array}$ & Chiao et al., 2017 \\
\hline & & $\begin{array}{l}\text { Collaborative networks provide: Intelligent } \\
\text { information management } \\
\text { Decision support }\end{array}$ & Costa et al., 2015 \\
\hline & International networks & $\begin{array}{l}\text { Close international network relationships } \\
\text { International alliances }\end{array}$ & $\begin{array}{l}\text { Bemborn, } 2018 \\
\text { Chang \& Mao, } 2015\end{array}$ \\
\hline & & $\begin{array}{l}\text { Institutional network and business network } \\
\text { (contacts to persons) }\end{array}$ & Falahat, 2018 \\
\hline & & External networking & Lin et al., 2018 \\
\hline & & Business networks & Neubert, 2016b \\
\hline
\end{tabular}




\begin{tabular}{|c|c|c|c|}
\hline & & Local formal and informal interpersonal networks & Idris \& Saridakis, 2018 \\
\hline & & $\begin{array}{l}\text { Networking competence mediate impact of } \\
\text { institutional factors }\end{array}$ & Torkkeli et al., 2019 \\
\hline & & Resources to establish international networks $(+)$ & Chahabadi, 2015 \\
\hline & & External linkage capabilities & Jain et al., 2019 \\
\hline \multirow[t]{10}{*}{ Category } & Determiners & Observed effects & Author, year \\
\hline & $\begin{array}{l}\text { Local \& international } \\
\text { networks }\end{array}$ & Network building of managerial team & Neubert, 2017 \\
\hline & & $\begin{array}{l}\text { Collaboration with further international high-tech } \\
\text { firms }\end{array}$ & $\begin{array}{l}\text { Neubert \& Van der Krogt, } \\
2020\end{array}$ \\
\hline & & Business network & Ooi \& Richardson, 2020 \\
\hline & & Effectual vs non-effectual network building & Prashantam et al., 2019 \\
\hline & & Supplier-customer relationships & Vahlne \& Bhatti, 2019 \\
\hline & Virtual networks & Social networks & Chang \& Mao, 2015 \\
\hline & & Social network engagement & Mihailova et al., 2015 \\
\hline & & $\begin{array}{l}\text { Utilization of global business hubs (highly } \\
\text { connected nodes) }\end{array}$ & Wild, 2020 \\
\hline & & $\begin{array}{l}\text { Alliance management capabilities } \\
\text { Co-innovation }\end{array}$ & $\begin{array}{l}\text { Zahoor \& Al-Tabbaa, } \\
2017\end{array}$ \\
\hline
\end{tabular}

\section{Conclusions}

\subsection{Overview of Empirical Review Results}

The review results on determiners and moderators of internationalization speed are condensed in a comprehensive model (Figure 1).

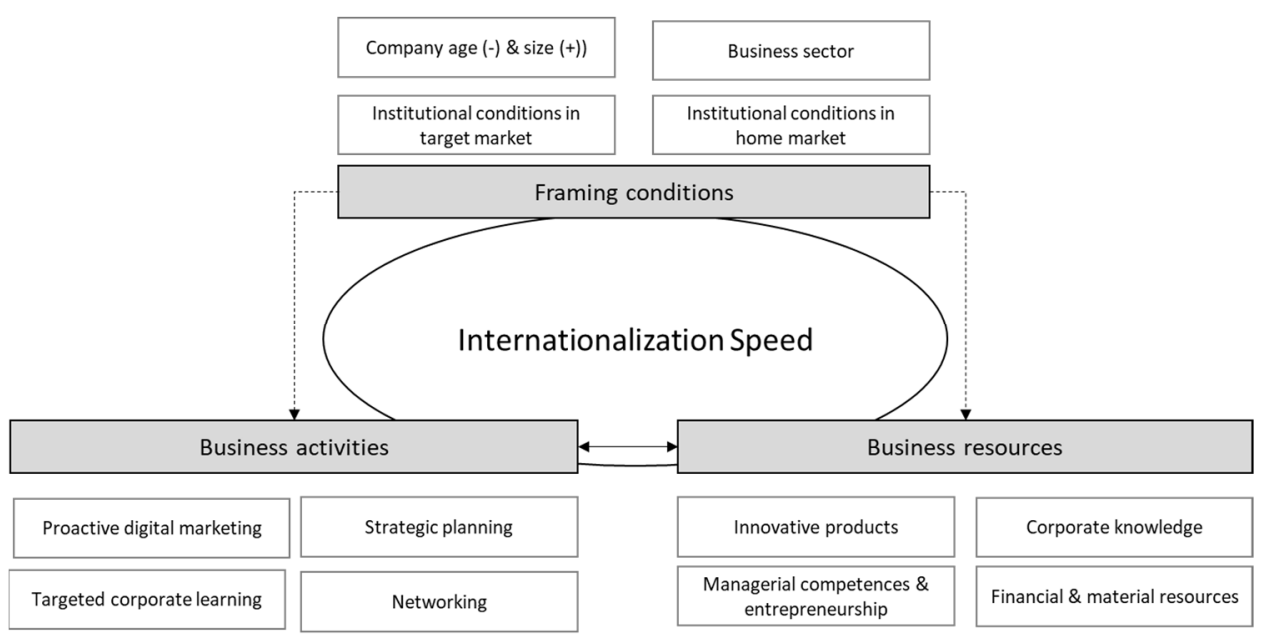

Figure 1. Overview on review results

Figure 1 classifies determiners of internationalization speed into framing conditions, business resources and business activities in accordance with the systematics developed from the review of internationalization theories in chapter 2. Figure 1 rearranges one item of the review of empirical studies: company age and size are classified as framing factors, since these are not changeable when deciding on internationalization. The chart shows that framing conditions partly codetermine and control the availability of business resources and the option to pursue certain business activities (dotted arrows). In spite of adverse conditions however, internationalization speed depends on businesses' resource stock, e.g. innovative products, the corporate knowledge base, managerial 
competence, entrepreneurial spirt and finally financial resources. Strategic thrusts enable businesses to develop resources, but partly business resources determine the extent to which certain strategic thrusts are possible (e.g. digital marketing requires IT knowhow). In sum, all three major factors - framing conditions, business resources and activities determine the speed of business internationalization.

\subsection{Gaps in Empirical Internationalization Speed Research and Call for Further Studies}

Based on the model of determiners of and the extensive review of recent empirical studies in internationalization speed, three important research gaps catch the eye:

Although the retrieved studies assess a very broad range of items, empirical research is certainly not conclusive concerning the considered potential determiners of internationalization speed, so far. Financial aspects have hardly been considered, and are mentioned by two authors (Bolzani, 2017; Schu et al., 2016), only. However, the availability of financial resources is fundamental to internationalization ventures and certainly a pacemaker of any activity in international contexts. The fact that internationalization further stimulates financial profitability and that this cycle is advanced with growing internationalization speed could be a new focus of internationalization speed research in future. Further potential pacemakers of internationalization speed hardly considered so far, are the availability of human resources e.g. technical experts or intrapreneurial employees. The aspiration to expand into international target countries has so far been considered from a marketing perspective only, assuming that expanding companies seek to offer their products or services abroad. Potential supply-side intentions, however, have hardly been evaluated yet. The acquisition of material physical resources e.g. rare minerals or the availability of cheap labor in low-wage countries could be important motivations to expand internationally. The analysis of the impact of these strategic aspirations on internationalization speed could be an interesting field of future empirical research.

Second there are important methodological biases which result in the neglection of potentially important causal relationships between determiners of internationalization speed. Since most studies use linear or logistic regression models, the relationships between the model factors are hardly assessed (e.g. Wach et al., 2018; Torkkeli et al., 2019; Mihailova, 2020; Mohr et al., 2018, Hutzschenreuter et al., 2019 and several others). Even empirical studies using structural equation models for analysis are reluctant to comprehensively explore the interrelationships between determiners of internationalization speed and refer to few parameters only, probably to limit model complexity (Chiao et al., 2017; Erikson et all., 2015). The retrieved qualitative empirical studies, however, suggest that a series of causal interrelationships between framing conditions, business activities and corporate resources exist, which are essential to the mode and timeline of businesses' internationalization behavior. The review-based model (figure 1) suggested here, mirrors only a rough outline of the diverse possible relationships at the level of part constructs and items. Since these relationships shine up through in-depth qualitative research mainly, which unfortunately is not representative, so far, no comprehensive systematics of the potential cause and effect chains has been retrieved and empirically validated for a large data set.

Finally, the only focus of empirical internationalization speed research is the target parameter internationalization speed. Only few studies suggest, that internationalization speed is not a desirable target by itself, rather internationalization speed is useful only if the chosen speed maximizes shareholder and stakeholder value sustainably. A negative impact of at age at initiation on internationalization speed has been found (Amann, 2016; Chun, 2020; du et al., 2020, Mihailova et al., 2015; Lattemann et al., 2015). However, none of the studies questions to what extent experienced companies operate more carefully and diligently in international markets to avoid high risk exposure. In correspondence, Chahabadi (2015) discovers that internationalization speed diminishes with management experience in international environments. Olmos \& Díez-Vial (2015) observe for exporting businesses that internationalization performance does not progress linearly with internationalization speed and that internationalization speed may change in time. Unfortunately, these results are limited to pure export companies from a single nation and sector (wine companies in Spain). Further in-depth research on the impact of internationalization speed and variations in speed on performance would be required.

\subsection{Potential Limitations and Outlook}

Although the study has provided a comprehensive overview on determiners of internationalization speed, it is certainly not comprehensive. First literature selection has been limited to publications in major peer-reviewed journals mainly, while further potentially valuable non-peer-reviewed studies have not been considered. Second the study has focused on recent publications (from 2015) while for page limitations earlier studies have been excluded. Compromising for evaluation depth within the framework of a meta-analysis, a broader sample of studies could have been considered. Although this study has developed comprehensive research propositions and a model draft, empirical validation of this approach is still outstanding and an important objective of follow-up 
research.

Businesses planning internationalization could still use the model to visualize the set screws of internationalization speed. Although the institutional and sectoral context of internationalization requires detailed consideration, businesses should not neglect their own potential to design international growth proactively by developing their inner resources and strategically planning their corporate development and networking activities sustainably.

\section{References}

Abrahamsson, J., \& Isaksson, A. (2018). The Knowledge-based resources of venture Capital firms' and born global firms' internationalization. ASEAN Journal of Management \& Innovation, 5(1), 30-46.

Altissimo, A. (2020). Internationalization myths and transnational realities. In Beings, Belongings and Places (pp. 3-12). Springer VS, Wiesbaden. https://doi.org/10.1007/978-3-658-31364-7_2

Amann, W., Baldegger, R., \& Schueffel, P. (2016). Linking internationalization age and speed in Swiss SMEs. In Proceedings of the 2016 ACERE Conference (No. CONFERENCE). 2-5 February 2016.

Amorós, J. E., Basco, R., \& Romaní, G. (2016). Determinants of early internationalization of new firms: the case of Chile. International Entrepreneurship and Management Journal, 12(1), 283-307. https://doi.org/10.1007/s11365-014-0343-2

Andersson, S., \& Evangelista, F. (2006). The entrepreneur in the born global firm in Australia and Sweden. Journal of Small Business and Enterprise Development, 13(4), 642-659. https://doi.org/10.1108/14626000610705796

Andersson, S., \& Wictor, I. (2003). Innovation internationalization in new firms: Born globals - the Swedish case. Journal of International Entrepreneurship, 1(3), 249-276. https://doi.org/10.1023/A:1024110806241

Ansoff, H. I. (1965). Corporate strategy: An analytic approach to business policy for growth and expansion. McGraw-Hill Companies.

Bembom, M. (2018). Early Internationalizing Firms: Networks and Post-Entry Internationalization Speed (Doctoral dissertation, Heinrich-Heine-Universität Düsseldorf).

Blankenburg, D., \& Johanson, J. (1992). Managing network connections in international business. Scandinavian international business review, 1(1), 5-19. https://doi.org/10.1016/0962-9262(92)90033-3

Bolzani, D., Fini, R., \& Grimaldi, R. (2017). The internationalization of academic spin-offs: Evidence from Italy. In The World Scientific Reference On Entrepreneurship: Process Approach to Academic Entrepreneurship-Evidence from the Globe (Volume 4, pp. 241-280). https://doi.org/10.1142/9789813220621_0010

Bovina, L. (2020). Digital Marketing and Internationalization Speed of Start-ups: Cases from Finnish energy sector. University of Vaasa, Mater Thesis.

Buckley, P. J., \& Casson, M. (2007). Edith Penrose's theory of the growth of the firm and the strategic management of multinational enterprises. Management International Review, 47(2), 151-173. https://doi.org/10.1007/s11575-007-0009-1

Buckley, P. J., \& Ghauri, P. (2015). The Uppsala internationalization process model revisited: from liability of foreignness to liability of outsidership. In International Business Strategy (pp. 47-73). Routledge. https://doi.org/10.4324/9781315848365

Cavusgil, S. T., Knight, G., \& Riesenberger, J. R. (2014). International Business - The New Realities. 3rd edition. Essex: Pearson Education.

Cavusgil, S. T., \& Knight, G. (2015). The born global firm: An entrepreneurial and capabilities perspective on early and rapid internationalization. Journal of International Business Studies, 46(1), 3-16. https://doi.org/10.1057/jibs.2014.62

Cesinger, B., Fink, M., Madsen, T. K., \& Kraus, S. (2012). Rapidly internationalizing ventures: how definitions can bridge the gap across contexts. Management Decision. https://doi.org/10.1108/00251741211279620

Chahabadi, D. (2016). Internationalization of firms: Antecedents, speed, and performance implications: Evidence from the German renewable-energy industry. Doctoral Thesis, University of Göttingen.

Chang, S., \& Mao, M. (2015). The Determinants of Internationalization Speed for International New Ventures (INVs). Halmstad University master's Thesis. 
Chang, R. X., \& Ogasavara, M. H. (2019). The impact of institutional distance and experiential knowledge on the internationalization speed of Japanese MNEs. Asian Business \& Management, 1-34. https://doi.org/10.1057/s41291-019-00093-z

Cheng, C., Zhong, H., \& Cao, L. (2020). Facilitating speed of internationalization: The roles of business intelligence and organizational agility. Journal of Business Research, 110, 95-103. https://doi.org/10.1016/j.jbusres.2020.01.003

Chetty, S. (1994). Business Networks as a Determinant of Export Performance. Journal of International Marketing, pp. 11-15.

Chetty, S., \& Blankenburg Holm, D. (2000). The Role of Business Networks in the Internationalization of Manufacturing Firms: A Longitudinal Case Study. Advances in International Marketing, 333-355.

Chetty, S., \& Campbell-Hunt, C. (2004). A strategic approach to internationalization: a traditional versus a "born-global" approach. Journal of International marketing, 12(1), 57-81. https://doi.org/10.1509/jimk.12.1.57.25651

Chiao, Y. C., Cheng, K. H., Lin, K. H., \& Yeh, S. C. (nd.). The Mediating Effect of Internal and External Network Resources on Internationalization and Performance. Journal of Contemporary Management, 8(4).

Chun, Y., \& Shin, M. (2020). Speed of Internationalization, the Knowledge Link and Effects of Creativity (Doctoral dissertation), Seoul National University.

Clermonts, M. (2019). The Internationalization Process of Emerging Market Multinationals. How institutional distance, cross-listing and absorptive capacity affect the scope and speed of the EMNE's Internationalization Process. Doctoral Thesis Radboud Universiteit Nijmegen.

Costa, E., Soares, A. L., \& De Sousa, J. P. (2015, October). A new insight in the SMEs internationalization process. In Working Conference on Virtual Enterprises (pp. 398-410). Springer, Cham. https://doi.org/10.1007/978-3-319-24141-8_36

De Oliveira Cabral, J. E., \& Schaefer, T. O. (2016) Born Global and Internationalization Theories-A Comparative Study

Du, H., Mitkova, L., \& Wang, N. (2020). The Paths of Internationalization of Chinese Innovative Firms. Sustainability, 12(6), 2575. https://doi.org/10.3390/su12062575

Elgar, E. (2003). Learning in the Internationalization Process of Firms. UK: JIBS Book Review.

Eriksson, K., Johanson, J., Majkgård, A., \& Sharma, D. D. (2015). Experiential knowledge and cost in the internationalization process. In Knowledge, networks and power (pp. 41-63). Palgrave Macmillan, London. https://doi.org/10.1057/9781137508829_2

Falahat, M., Knight, G., \& Alon, I. (2018). Orientations and capabilities of born global firms from emerging markets. International Marketing Review. https://doi.org/10.1108/IMR-01-2017-0021

Forsgren, M., \& Pahlberg, C. (1992). Managing international networks: presentation of a research project. Företagsekonomiska institutionen.

Forsgren, M., \& Johanson, J. (1992). Managing internationalization in business networks. Amsterdam: Gordon and Breach science publishers.

Forsgren, M., \& Johanson, J. (2014). Managing networks in international business. Routledge. https://doi.org/10.4324/9781315800417

Forsgren, M., Holm, U., \& Johanson, J. (2015). Knowledge, Networks and Power-The Uppsala School of International Business. In Knowledge, networks and power (pp. 3-38). London: Palgrave Macmillan. https://doi.org/10.1057/9781137508829_1

Forsgren, M. (2016). A note on the revisited Uppsala internationalization process model-the implications of business networks and entrepreneurship. Journal of International Business Studies, 47(9), 1135-1144. https://doi.org/10.1057/s41267-016-0014-3

Freeman, S., Hutchings, K., Lazaris, M., \& Zyngier, S. (2010). A model of rapid knowledge development: The smaller born-global firm. International Business Review, 19(1), 70-84. https://doi.org/10.1016/j.ibusrev.2009.09.004 
Freixanet, J., \& Renart, G. (2020). A capabilities perspective on the joint effects of internationalization time, speed, geographic scope and managers' competencies on SME survival. Journal of World Business, 55(6), 101110. https://doi.org/10.1016/j.jwb.2020.101110

Gabrielsson, M., \& Kirpalani, V. M. (2004). Born globals: how to reach new business space rapidly. International Business Review, 13(5), 555-571. https://doi.org/10.1016/j.ibusrev.2004.03.005

Genç, Ö. F. (2016). The Role of NGO-SME Cooperation in Internationalization Process and Performance of SMEs. International Journal of Trade, Economics and Finance, 7(6), 224. https://doi.org/10.18178/ijtef.2016.7.6.527

Głodowska, A., Pera, B., \& Wach, K. (2019). International Strategy as the Facilitator of the Speed, Scope, and Scale of Firms' Internationalization. Journal of Management and Business Administration. Central Europe, 27(3), 55-84. https://doi.org/10.7206/cemj.2658-0845.3

Guserl, A. (2013). Internationalisierungsprozesse und Finanzstrategien: Ansätze und empirische Analysen (p. 409). Peter Lang International Academic Publishers. https://doi.org/10.3726/978-3-653-02885-0

Harveston, P. D., Kedia, B. L., \& Davis, P. S. (2000). Internationalization of born global and gradual globalizing firms: The impact of the manager. Journal of Competitiveness Studies, 8(1), 92.

Hermannsdottir, A. (2008). Theoretical underpinnings of the internationalization process. Institute of Business research. ISSN 1670-7168.

Hill, C. (2007). International Business Competing in the Global Marketplace 6th ed. McGraw-Hill.

Hilmersson, M., \& Johanson, M. (2016). Speed of SME internationalization and performance. Management International Review, 56(1), 67-94. https://doi.org/10.1007/s11575-015-0257-4

Hilmersson, M., \& Johanson, M. (2020). Knowledge acquisition strategy, speed of capability development and speed of SME internationalization. International Small Business Journal. https://doi.org/10.1177/0266242620909029

Holm, D. B., Johanson, M., \& Kao, P. T. (2015). From outsider to insider: Opportunity development in foreign market networks. Journal of International Entrepreneurship, 13(3), 337-359. https://doi.org/10.1007/s10843-015-0154-8

Hsieh, L., Child, J., Narooz, R., Elbanna, S., Karmowska, J., Marinova, S., ... \& Zhang, Y. (2019). A multidimensional perspective of SME internationalization speed: The influence of entrepreneurial $\begin{array}{llll}\text { characteristics. } & \text { International } & \text { Business }\end{array}$ https://doi.org/10.1016/j.ibusrev.2018.09.004

Hurmerinta, L., Nummela, N., \& Paavilainen-Ma“ntyma“ki, E. (2015). Opening and closing doors: the role of language in international opportunity recognition and exploitation. International Business Review, 25(6), 1082-1094. https://doi.org/10.1016/j.ibusrev.2015.04.010

Hutzschenreuter, T., Kleindienst, I., Guenther, C., \& Hammes, M. (2016). Speed of internationalization of new business units: the impact of direct and indirect learning. Management International Review, 56(6), 849-878. https://doi.org/10.1007/s11575-016-0305-8

Idris, B., \& Saridakis, G. (2018) Local formal interpersonal networks and SMEs internationalization: Empirical evidence from the UK. International Business Review, 27(3), 610-624. https://doi.org/10.1016/j.ibusrev.2017.10.010

Ivanauskiene, N., Auruskeviciene, V., Ramoniene, L., \& Skudiene, V. (2015). The relationship among e-marketing strategy and success of internationalization process of the SMEs in emerging economies. European Journal of Business and Economics, 10(2). https://doi.org/10.12955/ejbe.v10i2.685

Jain, N. K., Celo, S., \& Kumar, V. (2019). Internationalization speed, resources and performance: Evidence from Indian software industry. Journal of Business Research, 95, 26-37. https://doi.org/10.1016/j.jbusres.2018.09.019

Johanson, J., \& Vahlne, J. E. (1977). The internationalization process of the firm-a model of knowledge development and increasing foreign market commitments. Journal of international business studies, 8(1), 23-32. https://doi.org/10.1057/palgrave.jibs.8490676

Johanson, J., \& Wiedersheim-Paul, F. (1975). The internationalization of the firm: Four Swedish cases. Journal of management studies, 12(3), 305-322. https://doi.org/10.1111/j.1467-6486.1975.tb00514.x 
Johanson, J., \& Vahlne, J. E. (2006). Commitment and opportunity development in the internationalization process: A note on the Uppsala internationalization process model. Management International Review, 46(2), 165-178. https://doi.org/10.1007/s11575-006-0043-4

Johanson, J., \& Vahlne, J. E. (2009). The Uppsala internationalization process model revisited: From liability of foreignness to liability of outsidership. Journal of international business studies, 40(9), 1411-1431. https://doi.org/10.1057/jibs.2009.24

Knight, G. A. (1997). Cross-cultural reliability and validity of a scale to measure firm entrepreneurial orientation. Journal of business venturing, 12(3), 213-225. https://doi.org/10.1016/S0883-9026(96)00065-1

Knight, G. A., \& Cavusgil, S. T. (1996). The born global firm: A challenge to traditional internationalization theory. Advances in international marketing, 8(1), 11-26.

Knight, G.A., \& Cavusgil, S. T. (2004). Innovation, organizational capabilities, and the born-global firm. Journal of International Business Studies, 35 (2), 124-141. https://doi.org/10.1057/palgrave.jibs.8400071

Knight, G. A., \& Liesch, P. W. (2016). Internationalization: From incremental to born global. Journal of World Business, 51(1), 93-102. https://doi.org/10.1016/j.jwb.2015.08.011

Kraus, S., Breier, M., \& Dasí-Rodríguez, S. (2020). The art of crafting a systematic literature review in entrepreneurship research. International Entrepreneurship and Management Journal, 1-20. https://doi.org/10.1007/s11365-020-00635-4

Kutschker, M., \& Schmid, S. (2011): Internationales Management (7th ed.). München: Oldenbourg. https://doi.org/10.1524/9783486719246

Kutschker, M., \& Schmid, S. (2006). Internationales Management. München.

Kwon, Y. C. and Hu, M. Y. (1995). Comparative analysis of export-oriented and foreign production-oriented firms' foreign market entry decisions. Management International Review, 35, 325-336.

Lattemann, C., Zhang, W., Yuan, L., \& Pangarkar, N. (2015). Performance implications of internationalization strategies for Chinese MNCs. International Journal of Emerging Markets.

Lee, H., Kelley, D., Lee, J., \& Lee, S. (2012). SME survival: The impact of internationalization, technology resources, and alliances. Journal of small business management, 50(1), 1-19. https://doi.org/10.1111/j.1540-627X.2011.00341.x

Li, G. (2020). A Review of the Literature of the Relationship between Innovation and Internationalization of SMEs and Future Prospects. American Journal of Industrial and Business Management, 10(03), 619. https://doi.org/10.4236/ajibm.2020.103041

Lin, S., Mercier-Suissa, C., \& Salloum, C. (2016). The Chinese born globals of the Zhejiang Province: A study on the key factors for their rapid internationalization. Journal of International Entrepreneurship, 14(1), 75-95. https://doi.org/10.1007/s10843-016-0174-z

Lumpkin, G. T., \& Dess, G. G. (2015). Entrepreneurial orientation. Wiley Encyclopedia of Management, 1-4. https://doi.org/10.1002/9781118785317.weom030030

Luostarinen, R. (1979). Internationalization of the Firm. Helsinki: Acta Academiae Oeconomicae Helsingienis, Helsinki School of Economics.

Luostarinen, R. (1994). Internationalization of Finnish firms and their response to global challenges. UNU World Institute for Development Economics Research

Luostarinen, R., \& Gabrielsson, M. (2006). Globalization and marketing strategies of born globals in SMOPECs. Thunderbird International Business Review, 48(6), 773-801. https://doi.org/10.1002/tie.20122

Macharzina, K. (1982). Theorie der internationalen Unternehmenstätigkeit-Kritik und Ansätze $r$ integrativen Modellbildung. Univ. Hohenheim.

Macharzina, K., \& Engelhard, J. (1991). Paradigm shift in international business research: From partist and eclectic approaches to the GAINS paradigm. MIR: Management International Review, 23-43.

Madsen, T. K., \& Servais, P. (1997). The internationalization of born globals: an evolutionary process? International business review, 6(6), 561-583. https://doi.org/10.1016/S0969-5931(97)00032-2 
Matiusinaite, A., \& Sekliuckiene, J. (2015, October). Factors determining early internationalization of entrepreneurial SMEs: Theoretical approach. In DIEM: Dubrovnik International Economic Meeting (Vol. 2, No. 1, pp. 175-185). Sveučilište u Dubrovniku.

Melin, L. (1992). Internationalization as a strategy process. Strategic Management Journal, 13, 99-118. https://doi.org/10.1002/smj.4250130908

Mihailova, I., Shirokova, G., \& Laine, I. (2015). New venture internationalization from an emergent market: unexpected findings from Russia. Journal of East-West Business, 21(4), 257-291. https://doi.org/10.1080/10669868.2015.1067276

Mohr, A., Batsakis, G., \& Stone, Z. (2018). Explaining the effect of rapid internationalization on horizontal foreign divestment in the retail sector: An extended Penrosean perspective. Journal of International Business Studies, 49(7), 779-808. https://doi.org/10.1057/s41267-017-0138-0

Neubert, M. (2015). Early internationalisation of high-tech firms: Past accomplishments and future directions. International Journal of Teaching and Case Studies, 6(4), 353-369. https://doi.org/10.1504/IJTCS.2015.074603

Neubert, M. (2016a). Significance of the speed of internationalization for born global firms-a multiple case study approach. International Journal of Teaching and Case Studies, 7(1), 66-81. https://doi.org/10.1504/IJTCS.2016.076067

Neubert, M. (2016b). How and why born global firms differ in their speed of internationalisation-a multiple case study approach. International Journal of Teaching and Case Studies, 7(2), 118-134. https://doi.org/10.1504/IJTCS.2016.078168

Neubert, M. (2017). Lean Internationalization: How to globalize early and fast in a small economy. Technology Innovation Management Review, 7(5). https://doi.org/10.22215/timreview/1073

Neubert, M. (2018a). The impact of digitalization on the speed of internationalization of lean global startups. Technology Innovation Management Review, 8(5). https://doi.org/10.22215/timreview/1158

Neubert, M. (2018b). Internationalization behaviour of small and medium-sized enterprises from emerging markets: implications for sustainability. Latin American Journal of Management for Sustainable Development, 4(3), 226-238. https://doi.org/10.1504/LAJMSD.2018.096072

Neubert, M., \& Van der Krogt, A. (2017). Lean internationalization of high-tech firms. International Journal of Teaching and Case Studies, 8(2-3), 133-150. https://doi.org/10.1504/IJTCS.2017.086679

Neubert, M., \& Van der Krogt, A. (2018). Impact of business intelligence solutions on export performance of software firms in emerging economies. Technology Innovation Management Review, 8(9), 39-49. http://doi.org/10.22215/timreview/1185

Neubert, M., \& Van der Krogt, A. S. (2020). Decision-makers impact on the internationalization of high-technology firms in emerging markets. Journal of Global Entrepreneurship Research, 10(1), 1-17. https://doi.org/10.1186/s40497-019-0195-x

Niittymies, A., \& Pajunen, K. (2019). Cognitive foundations of firm internationalization: A systematic review and agenda for future research. International Business Review, 101654.Rasmussen, E. S., \& Madsen, T. K. (2002, December). The born global concept. In Paper for the EIBA conference (pp. 1-26). https://doi.org/10.1016/j.ibusrev.2019.101654

O'Farrell, P. N., \& Hitchens, D. M. (1988). Alternative theories of small-firm growth: a critical review. Environment and Planning A, 20(10), 1365-1383. https://doi.org/10.1068/a201365

Olmos, M. F., \& Díez-Vial, I. (2015). Internationalization pathways and the performance of SMEs. European Journal of Marketing, 49(3/4), 420-443. https://doi.org/10.1108/EJM-06-2012-0365

Ooi, S. M., \& Richardson, C. (2019). The internationalization of service-sector SMEs in an emerging market. Review of International Business and Strategy. https://doi.org/10.1108/RIBS-02-2018-0023

Oviatt, B. M., \& McDougall, P. P. (1994). Toward a theory of international new ventures. Journal of International Business Studies, 25(1). 45-64. https://doi.org/10.1057/palgrave.jibs.8490193

Paul, J., \& Rosado-Serrano, A. (2019). Gradual internationalization vs born-global/international new venture models. International Marketing Review, 36(6), 830-858. https://doi.org/10.1108/IMR-10-2018-0280

Penrose, E. (1959). The theory of the growth of the firm Blackwell. London, UK. 
Prashantham, S., Kumar, K., Bhagavatula, S., \& Sarasvathy, S. D. (2019). Effectuation, network-building and internationalization speed. International Small Business Journal, 37(1), 3-21. https://doi.org/10.1177/0266242618796145

Rasmussen, E. S., \& Madsen, T. K. (2002, December). The born global concept. In Paper for the EIBA conference (pp. 1-26).

Ratajczak-Mrozek, M. (2017). Relationships and Interactions as the Basis of Companies' Activities. In Network Embeddedness (pp. 61-86). Palgrave Macmillan, Cham. https://doi.org/10.1007/978-3-319-56511-8_3

Rennie, M. W. (1993). Born global. The McKinsey Quarterly, (4), 45-53.

Rialp-Criado, J., \& Rialp, A. (2020). Speed of Use of Social Media as an Antecedent of Speed of Business Internationalization. Journal of Global Information Management (JGIM), 28(1), 142-166. https://doi.org/10.4018/JGIM.2020010108

Saghebi, S., Alizadeh, A., Mohammadzaheri, M., \& Habibisenobari, T. (2019). Relationships of managers' entrepreneurial perception and internationalization speed in small and medium-sized enterprises (SMEs). Journal of Global Entrepreneurship Research, 9(1), 28. https://doi.org/10.1186/s40497-019-0151-9

Schu, M., Morschett, D., \& Swoboda, B. (2016). Internationalization speed of online retailers: A resource-based perspective on the influence factors. Management International Review, 56(5), 733-757. https://doi.org/10.1007/s11575-016-0279-6

Sikorski, D. and Menkhoff, T. (2000). Internationalization of Asian business. Singapore Management Review, $22,1-17$

Swoboda, B. (2002). Dynamische Prozesse der Internationalisierung: managementtheoretische und empirische Perspektiven des unternehmerischen Wandels. Dt. Univ.-Verlag.

Tanev, S. (2012). Global from the start: The characteristics of born-global firms in the technology sector. Technology Innovation Management Review, 2(3). https://doi.org/10.22215/timreview/532

Torkkeli, L., Kuivalainen, O., Saarenketo, S., \& Puumalainen, K. (2019). Institutional environment and network competence in successful SME internationalization. International Marketing Review. https://doi.org/10.1108/IMR-03-2017-0057

Tsao, S. M., \& Chen, G. Z. (2012). The impact of internationalization on performance and innovation: The moderating effects of ownership concentration. Asia Pacific Journal of Management, 29(3), 617-642. https://doi.org/10.1007/s10490-010-9217-5

Vahlne, J. E., \& Bhatti, W. A. (2019). Relationship development: A micro-foundation for the internationalization process of the multinational business enterprise. Management International Review, 59(2), 203-228. https://doi.org/10.1007/s11575-018-0373-z

Vlacic, B. (2018). The role of managerial cognitive reasoning on the internationalization decision-making of small ventures (Doctoral dissertation, Organización de empresas e márketing).

Wach, K., Głodowska, A., \& Maciejewski, M. (2018). Entrepreneurial orientation, knowledge utilization and internationalization of firms. Sustainability, 10(12), 4711. https://doi.org/10.3390/su10124711

Webster, J., \& Watson, R. T. (2002). Analyzing the past to prepare for the future: Writing a literature review. MIS Quarterly, 13-23.

Welch, L. S., \& Luostarinen, R. (1988). Internationalization: Evolution of a concept. Journal of general management, 14(2), 34-55. https://doi.org/10.1177/030630708801400203

Welch, C., Nummela, N., \& Liesch, P. (2016). The internationalization process model revisited: An agenda for future research. Manag Int Rev., 56, 783-804. https://doi.org/10.1007/s11575-016-0302-y

Wild, P. (2020). The Importance of Global Business Hubs on Internationalizing SMEs: an empirical analysis of psychic and geographic distance. Technology innovation management review, 10(4). https://doi.org/10.22215/timreview/1345

Wührer, G. A. (2015). Gestalt-and Network Approach-Avenues to a New Paradigm of Internationalization Theory? In Proceedings of the 1993 World Marketing Congress (pp. 155-158). https://doi.org/10.1007/978-3-319-17323-8_37 
Vahlne, J. E., \& Bhatti, W. A. (2019). Relationship development: A micro-foundation for the internationalization process of the multinational business enterprise. Management International Review, 59(2), 203-228. https://doi.org/10.1007/s11575-018-0373-z

Vahlne, J. E., \& Johanson, J. (2017). From internationalization processes 1977 to evolution 2017-The Uppsala model 40 years. Journal of International Business Studies, 48(9), 1087-1102. https://doi.org/10.1057/s41267-017-0107-7

Vahlne, J. E., \& Johanson, J. (2020). The Uppsala model: Networks and micro-foundations. Journal of International Business Studies, 51(1), 4-10. https://doi.org/10.1057/s41267-019-00277-X

Vătămănescu, E. M., Andrei, A. G., Nicolescu, L., Pînzaru, F., \& Zbuchea, A. (2017). The influence of competitiveness on SMEs internationalization effectiveness. Online versus offline business networking. Information Systems Management, 34(3), 205-219. https://doi.org/10.1080/10580530.2017.1329997

Verbeke, A. (2020). The JIBS 2019 Decade Award: The Uppsala internationalization process model revisited: From liability of foreignness to liability of outsidership. Journal of International Business Studies, 51(1), 1-3. https://doi.org/10.1057/s41267-019-00292-y

Vernon, R. (1966): International Investment and International Trade in the Product Cycle. In The Quarterly Journal of Economics, 80(2), 190-207. https://doi.org/10.2307/1880689

Vernon, R. (1979). The product cycle hypothesis in a new international environment. Oxford bulletin of economics and statistics, 41(4), 255-267. https://doi.org/10.1111/j.1468-0084.1979.mp41004002.x

Yamin, M., \& Kurt, Y. (2018). Revisiting the Uppsala internationalization model. International Marketing Review, 35(1), 2-17. https://doi.org/10.1108/IMR-11-2014-0345

Yoon, J., Sung, S., \& Ryu, D. (2020). The Role of Networks in Improving International Performance and Competitiveness: Perspective View of Open Innovation. Sustainability, 12(3), 1269. https://doi.org/10.3390/su12031269

Zahoor, N., \& Al-Tabbaa, O. (2017). Alliance Management Capabilities and Internationalization Performance of SMEs: The Mediating Role of Strategic Activity.

\section{Copyrights}

Copyright for this article is retained by the author(s), with first publication rights granted to the journal.

This is an open-access article distributed under the terms and conditions of the Creative Commons Attribution license (http://creativecommons.org/licenses/by/4.0/). 